\title{
Vascular nitric oxide: formation and function
}

This article was published in the following Dove Press journal:

Journal of Blood Medicine

II August 2010

Number of times this article has been viewed

\author{
Richard C Jin ${ }^{1,2}$ \\ Joseph Loscalzo' \\ 'Cardiovascular Division, Department \\ of Medicine, Brigham and Women's \\ Hospital, Harvard Medical School, \\ Boston, MA, USA; ${ }^{2}$ Boston University \\ School of Medicine, Boston, MA, USA
}

Correspondence: Joseph Loscalzo Brigham and Women's Hospital, 75 Francis Street, Boston, MA 02I I5, USA Tel + I-617-732-6340

$\mathrm{Fax}+\mathrm{I}-6 \mid \mathrm{I}-732-6439$

Email jloscalzo@partners.org

\begin{abstract}
Nitric oxide (NO) is a structurally simple, highly versatile molecule that was originally discovered over 30 years ago as an endothelium-derived relaxing factor. In addition to its vasorelaxing effects, NO is now recognized as a key determinant of vascular health, exerting antiplatelet, antithrombotic, and anti-inflammatory properties within the vasculature. This shortlived molecule exerts its inhibitory effect on vascular smooth muscle cells and platelets largely through cyclic guanosine monophosphate-dependent mechanisms, resulting in a multitude of molecular effects by which platelet activation and aggregation are prevented. The biosynthesis of NO occurs via the catalytic activity of NO synthase, an oxidoreductase found in many cell types. NO insufficiency can be attributed to limited substrate/cofactor availability as well as interactions with reactive oxygen species. Impaired NO bioavailability represents the central feature of endothelial dysfunction, a common abnormality found in many vascular diseases. In this review, we present an overview of NO synthesis and biochemistry, discuss the mechanisms of action of NO in regulating platelet and endothelial function, and review the effects of vascular disease states on NO bioavailability.
\end{abstract}

Keywords: platelets, endothelium, vasculature

\section{Introduction}

Nitric oxide (NO) is a structurally simple molecule that exerts effects on a wide variety of actions in the vasculature. NO was first discovered in 1980 by Furchgott and Zawadzki ${ }^{1}$ as an endothelium-derived relaxing factor, it has been recognized as a key determinant of vascular homeostasis, regulating several physiological properties of the blood vessel, including vasodilation, vascular permeability, and antithrombotic properties. $^{2}$ The bioavailability of NO represents a central feature of the normal vascular phenotype required for maintaining vasodilator tone and inhibiting platelet activation, thereby preventing thrombosis and its clinical vascular consequences. Decreased production or increased metabolism of NO may lead to NO insufficiency within the vasculature and its pathobiological consequences. This review begins with an overview on NO's ability to modulate vascular tone and platelet activity, discusses the biochemical pathways involved in metabolism of NO, briefly summarizes factors controlling NO synthase (NOS) activity, discusses the impact of vascular pathologies on $\mathrm{NO}$ and vice versa, and comments on pharmacological therapies for restoring vascular NO and their therapeutic utility. 


\section{Vascular actions of nitric oxide Vascular tone}

$\mathrm{NO}$ is a major regulator of vascular homeostasis, acting in various ways to regulate vascular tone. Low levels of NO produced by the endothelial cell play a key role maintaining vasorelaxation by exerting its effects on vascular smooth muscle cells (VSMCs), the contractile state of which defines vascular tone. NO produced within the cytosol of endothelial cells diffuses rapidly into adjacent VSMCs, exerting paracrine effects by activating soluble guanylyl cyclase to increase the synthesis of 3,5-cyclic guanosine monophosphate (cGMP). NO also decreases cytosolic $\mathrm{Ca}^{2+}$ concentration through inhibition of voltage-gated $\mathrm{Ca}^{2+}$ channels ${ }^{3}$ and activates protein kinases that phosphorylate proteins in the sarcoplasmic reticulum, as well as $\mathrm{Ca}^{2+}$-dependent potassium channels. ${ }^{3}$ Reduction in cytosolic $\mathrm{Ca}^{2+}$ concentration results in inhibition of calcium-calmodulin myosin light chain kinase complex formation in the VSMC, promoting vasorelaxation. ${ }^{4}$

Low levels of NO released by endothelial cells are critical for the maintenance of basal vascular tone. The synthesis of endothelial NO is increased in response to biochemical stimuli, including thrombin, adenosine diphosphate (ADP), serotonin, acetylcholine, and bradykinin; as well as mechanical stimuli, including shear stress and cyclic strain. Studies have previously shown that inhibition of NO synthesis in the vasculature may lead to hypertension ${ }^{5}$ or ischemic stroke, ${ }^{6}$ likely, in part, through its effects not only on vascular tone, but also on thrombotic potential. ${ }^{7}$

In addition to the ability of NO to regulate basal vascular tone, NO has also been found to influence stimulated endothelial release of tissue-type plasminogen activator (t-PA). Tissue-type plasminogen activator acts as the primary activator of endogenous fibrinolysis by converting the inactive proenzyme plasminogen to the active enzyme plasmin. Studies regarding the release of t-PA have thus far been conflicting, with some studies showing an inhibitory effect of NO on t-PA release ${ }^{8,9}$ and another showing the opposite. ${ }^{10}$ The role of NO in modulating t-PA still remains unclear; however, a possible explanation for the inhibitory effect of $\mathrm{NO}$ on t-PA release may be attributed to acute NO deprivation invoking a protective response resulting in greater endothelial t-PA release. Conversely, a possible explanation supporting NO-induced t-PA release as seen in Giannarelli's study may be due to the lower concentration of $\mathrm{L}-\mathrm{N}^{\mathrm{G}}$-monomethyl arginine citrate, a NOS inhibitor, $1 \mathrm{mg} / \mathrm{min}$, compared with the 2 previously mentioned studies by Smith et $\mathrm{al}^{8}$ and Pretorius and Brown, ${ }^{9} 5 \mathrm{mg} / \mathrm{min}$ and $3 \mathrm{mg} / \mathrm{min}$, respectively. Further studies are needed to elucidate NO's role in endothelial t-PA modulation.

\section{Platelet function and formation}

NO plays a key role in maintaining vascular integrity and blood flow by modulating platelet-endothelial interactions. ${ }^{11}$ Although platelets play an important role in hemostatic plug formation and wound healing, hyperreactivity can lead to vascular thrombosis and its clinical sequelae. ${ }^{7}$ Platelets normally circulate in an inactive state, suppressed by 3 biochemical systems: prostacyclin, ecto-AD(T)Pase/CD39, and NO. ${ }^{12}$ Prostacyclin, the main product of arachidonic acid metabolism in endothelial cells, ${ }^{13}$ inhibits platelets via cAMP-dependent mechanisms that include direct inhibition of $\mathrm{Ca}^{2+}$ mobilization and granule release. ${ }^{14}$ Ecto-AD(T)Pase is responsible for inhibition of platelet function by decreasing ADP-induced platelet aggregation ${ }^{15}$ and also indirectly by inhibiting the thromboxane $\mathrm{A}_{2}\left(\mathrm{TXA}_{2}\right.$ ) receptor ${ }^{16}$ (see later).

Calcium plays a central role as a second messenger in platelets. Concentrations within resting platelets are maintained between 50 and $100 \mathrm{nM}$, and upon activation, can achieve levels as high as $1 \mathrm{mM} .{ }^{17} \mathrm{An}$ increase in $\mathrm{Ca}^{2+}$ concentration within platelets leads to cytoskeletal rearrangement, shape change, and platelet granule secretion, ultimately resulting in aggregation. ${ }^{12}$ Platelet-associated $\mathrm{Ca}^{2+}$-binding proteins include alpha-helix, loop, second alpha-helix (EF-hand) proteins, and $\mathrm{Ca}^{2+}$-phospholipid binding proteins. ${ }^{18}$ Calmodulin is an EF-hand protein that binds to alpha-granules and is associated mechanistically with the $\mathrm{Ca}^{2+}$-calmodulin-induced phosphorylation of myosin light chain contributing to platelet granule secretion. ${ }^{19,20}$ Synaptotagmin, a $\mathrm{Ca}^{2+}$-phospholipid binding protein, has been associated with the regulation of dense granule secretion, ${ }^{21}$ further contributing to platelet activation and aggregation.

NO exerts its inhibitory effects on platelets via cGMP production and a secondary $\mathrm{Ca}^{2+}$-adenosine triphosphatase (ATPase)-dependent refilling of $\mathrm{Ca}^{2+}$ stores. ${ }^{22}$ Increased NO-stimulated guanylyl cyclase activity results in decreased intracellular $\mathrm{Ca}^{2+}$ levels through the inhibition of receptormediated $\mathrm{Ca}^{2+}$ release from the dense tubular system, an increased rate of $\mathrm{Ca}^{2+}$ extrusion, and decreased $\mathrm{Ca}^{2+}$ entry from the extracellular environment. In addition, $\mathrm{NO}$ increases sarcoplasmic reticulum $\mathrm{Ca}^{2+}$-ATPase activity via cGMPdependent protein kinase G-mediated phosphorylation of phosphlamban, ${ }^{23}$ which results in lower $\mathrm{Ca}^{2+}$ available for participating in activation/aggregation mechanisms. 
NO's ability to regulate cGMP is the principal determinant of its platelet inhibitory actions. The mechanisms by which cGMP-associated inhibition of platelets occurs include not only a decrease in intracellular $\mathrm{Ca}^{2+}$ concentration by the mechanisms described earlier, but also impaired expression of the active (fibrinogen binding) conformation of glycoprotein (GP) IIb/IIIa and decreased plateletbound fibrinogen. For hemostatic plug formation to take place, platelets must interact with one another by forming crosslinks with cell surface receptors, thereby leading to aggregation. Fibrinogen, a bivalent molecule, bridges adjacent activated platelets via the platelet GPIIb/IIIa integrin receptors. Cyclic GMP reduces the total number of conformationally active GPIIb/IIIa receptors on the platelet surface via inhibition of thrombin-mediated activation of phophoinositide 3-kinase ${ }^{24}$ and increases in the dissociation constant between fibrinogen and the GPIIb/IIIa receptor, resulting in unfavorable conditions for platelet aggregation. The resulting decrease in fibrinogen binding has been shown to be dose-dependent and strongly correlated with NO-dependent cGMP production. ${ }^{25} \mathrm{TXA}_{2}$, an eicosanoid produced via arachadonic acid metabolism within the platelet, contributes to platelet aggregation by mediating platelet GPIIb/IIIa expression. The TXA 2 receptor serves as a substrate for cGMP-dependent protein kinase and cGMP itself, ${ }^{16}$ leading to impaired receptor function, thereby representing another mechanism by which $\mathrm{NO}$ inhibits platelet activation. Furthermore, cGMP regulates the expression of the platelet (and endothelial) surface adhesion molecule P-selectin, in part, through the down-regulation of protein kinase $\mathrm{C}(\mathrm{PKC}) .{ }^{26}$

NO has also been shown to modulate megakaryocyte apoptosis. Megakaryocytes are responsible for platelet production, and factors affecting their viability may ultimately affect platelet formation (thrombopoiesis). Battinelli and Loscalzo ${ }^{27}$ investigated the role of $\mathrm{NO}$ on apoptosis in megarkaryocyte cell lines and found that NO induced apoptosis. They reported that both endogenous and exogenous sources of NO regulated apoptosis in Meg-01 and human erythroleukemia megakaryocytoid cell lines via modulation of the Bcl-2 family of proteins. This same group further investigated the role of NO-induced apoptosis on platelet formation by exploring the role of $\mathrm{NO}$ in the terminal stages of megakaryocytopoiesis. They found that NO-induced apoptosis in megakaryocytes resulted in platelet production. ${ }^{28}$ Thus, NO has effects on platelet production from megakaryocytes as well as on platelet function itself.

\section{Nitric oxide synthesis and biochemistry}

\section{Nitric oxide synthesis}

NO synthesis occurs in a range of cell types and tissues within the vasculature, including platelets, macrophages, and the vascular endothelium..$^{29} \mathrm{~A}$ class of enzymes known as NOS includes neuronal NOS (nNOS), endothelial NOS (eNOS), and inducible NOS (iNOS), all sharing between $50 \%$ and $60 \%$ sequence homology. ${ }^{30}$ All 3 isoforms catalyze a 5 -step electron oxidation of the terminal guanidino nitrogen atom of L-arginine to produce L-citrulline and NO. ${ }^{31}$ Enzyme activity requires flavin mononucleotide, flavin adenine dinucleotide, tetrahydrobiopterin $\left(\mathrm{BH}_{4}\right), \mathrm{Ca}^{2+}$-calmodulin, and heme, which serve as cofactors, along with nicotinamide adenine dinucleotide phosphate (NADPH) and molecular oxygen, which serve as cosubstrates. ${ }^{32}$

$\mathrm{NO}$ is an uncharged radical molecule approximately 70 times more soluble in hydrophobic environments than in water, enabling it to diffuse readily across cell membranes. Owing to its relatively short half-life, NO acts primarily in local environments. After synthesis, NO diffuses across biological membranes into specific target cells where it stimulates guanylyl cyclase to produce cGMP from guanosine triphosphate (GTP). ${ }^{33}$ Biological responses mediated by cGMP second messenger pathways described earlier are the principal, but not exclusive, action of $\mathrm{NO}^{34}$

The 3 NOS isoforms are characterized by their site of synthesis, pattern of expression, and $\mathrm{Ca}^{2+}$ dependency: NOS I or nNOS is expressed primarily in neurons; NOS II or iNOS, initially isolated from cytokine-induced macrophages, is now recognized as located in macrophages, neutrophils, platelets, and VSMCs, as well as in other nonvascular cells; NOS III or eNOS is constitutively expressed in endothelial cells. ${ }^{35}$ Each NOS isoform is comprised of an N-terminal oxygenase domain and a $\mathrm{C}$-terminal reductase domain with a calmodulin recognition sequence between the $2 .{ }^{36} \mathrm{NOS}$ activity is regulated by changes in intracellular $\mathrm{Ca}^{2+}$ concentration that affect the binding of calmodulin for efficient electron transfer from NADPH to the heme iron, which then catalyzes NO synthesis. ${ }^{37}$ The constitutively expressed NOS isoforms (nNOS and eNOS) are membrane-associated and bind calmodulin in a rapidly reversible and strongly $\mathrm{Ca}^{2+}$-dependent manner to regulate their activity.

When endothelial cells are activated by a receptor-mediated agonist, such as acetylcholine or bradykinin, or mechanical stimuli, such as shear stress, $\mathrm{Ca}^{2+}$ is transiently released from intracellular stores via a second messenger cascade involving inositol triphosphate, resulting in $\mathrm{Ca}^{2+}$-calmodulin complex-dependent activation of eNOS. NO production 
by eNOS is transient, paralleling intracellular $\mathrm{Ca}^{2+}$ levels. ${ }^{38}$ Endothelial NOS produces NO in the nanomolar range, a concentration that decreases with decreasing intracellular $\mathrm{Ca}^{2+}$ concentration, associated with the cytoprotective effects of $\mathrm{NO}$ and effective regulation of vascular tone. Unlike eNOS and nNOS, iNOS is less susceptible to changes in intracellular $\mathrm{Ca}^{2+}$ concentration, binding more avidly to calmodulin at the low $\mathrm{Ca}^{2+}$ concentrations found in resting cells. ${ }^{39} \mathrm{NO}$ production by iNOS is regulated at the transcriptional level, stimulated mainly by cytokines and microbial products (endotoxin), ${ }^{40}$ resulting in NO production in the micromolar range; these concentrations have been associated with mitochondrial membrane pore transition and caspase activation, resulting in apoptosis and necrosis. ${ }^{41}$ These elevated levels of $\mathrm{NO}$ are associated with the general cytotoxic effects of NO.

\section{Nitric oxide bioreactivity}

NO can exist in 3 closely interrelated redox forms: the free radical (NO), nitrosonium $\left(\mathrm{NO}^{+}\right)$resulting from a 1-electron oxidation of $\mathrm{NO}$, and nitroxyl anion $\left(\mathrm{NO}^{-}\right)$resulting from a 1-electron reduction of $\mathrm{NO}^{42}$ Each redox form has distinct chemical properties and reactivity. The major metabolic product of NO in aqueous solutions is nitrite. These NO species $\left(\mathrm{NO}_{x}\right)$ (reactive nitrogen species) and, in some cases, NO itself, can interact with molecular oxygen, thiols, reduced hemoproteins, and redox metals that conspire to determine its half-life and metabolism in biological systems. Some of these interactions include the reaction of $\mathrm{NO}$ with heme iron that leads to guanylyl cyclase activation resulting in cGMP formation; and the reaction of nitrosonium with - SH groupcontaining biomolecules in the presence of molecular oxygen to produce S-nitrosothiols (RSNO). S-nitrosothiols are relatively stable compared with $\mathrm{NO}$ and may represent a storage pool for bioavailable NO. ${ }^{43,44} \mathrm{~S}$-nitrosoalbumin accounts for the majority of RSNO in human plasma, and, along with other S-nitrosothiols, protects NO from inactivation with an approximate half-life ranging from 15 to 40 minutes in circulating blood. Cysteine is the sole thiol source in proteins and also constitutes the reactive thiol residue of glutathione. S-nitrosoglutathione (GSNO) possesses an approximate half-life of 8 minutes in the circulating blood. Biological actions of RSNO may be associated with heterolytic as well as homolytic mechanisms of decomposition resulting in 1 of the 3 NO redox forms. Heterolytic pathways of RSNO decomposition have been associated with many biological activities of NO. ${ }^{45}$ The substantially slower reaction rates between superoxide and RSNO compared with superoxide and NO suggest that the RSNO stabilizes NO protecting it from oxidative inactivation and thereby increasing its bioavailability. ${ }^{46}$ In addition, as many S-nitrosoproteins ${ }^{47}$ form via trans-S-nitrosation from GSNO, GSNO reductase ${ }^{48}$ is an important regulator of the bioavailability of (RS)NO.

The ability of NO to form a complex with hemoglobin $(\mathrm{Hb})$ is a recent emerging concept unveiling a vital physiological function in the setting of hypoxic vasodilation. $\mathrm{Hb}$ becomes S-nitrosylated on a specific cysteine residue on the $\beta$-chain ( $\beta$ Cys93) as red blood cells become oxygenated in the lungs, resulting in $\mathrm{SNO}-\mathrm{Hb}$ formation. This complex, SNO-Hb, exists in 2 conformational states, the R-state (relaxed and unreactive state, high oxygen affinity $\mathrm{Hb}$ conformation) and the T-state (tense reactive state, low oxygen affinity $\mathrm{Hb}$ conformation) in which $\mathrm{SNO}-\mathrm{Hb}$ can rapidly react with thiols and elicit a vasodilatory response within the vasculature. ${ }^{49,50}$ Dysfunction in this pathway has been shown to be associated with congestive heart failure, ${ }^{51}$ diabetes, ${ }^{52}$ and pulmonary hypertension. ${ }^{53}$ This SNO-Hb paradigm, recently reviewed by Allen et al, ${ }^{54}$ could have therapeutic implications for diseases involving abnormal microcirculatory perfusion.

NO can react with molecular oxygen and several reactive oxygen species (ROS), as shown in Figure 1, including superoxide anion $\left(\mathrm{O}_{2}^{-}\right)$, hydrogen peroxide $\left(\mathrm{H}_{2} \mathrm{O}_{2}\right.$; indirectly), and hydroxyl radical $(\mathrm{OH})$, to limit its bioactivity. Both endothelial

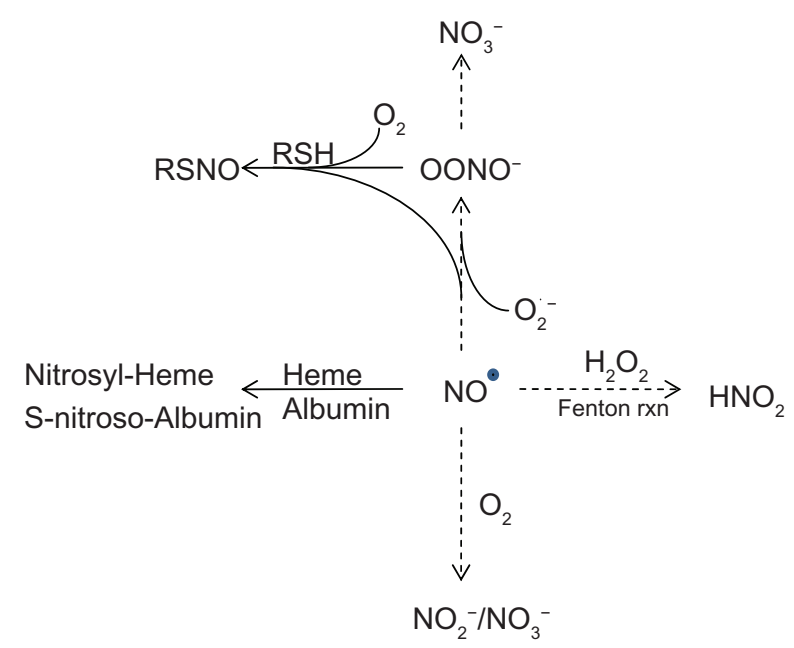

Figure I Biological reactions of nitric oxide. The free radical nitric oxide (NO) can react with many constituents within the vasculature that affect its bioavailability. $\mathrm{NO}$ can undergo oxidative inactivation (reactions shown in dashed lines) to form nitrite $\left(\mathrm{NO}_{2}^{-}\right)$and nitrate $\left(\mathrm{NO}_{3}^{-}\right)$. Other biologically relevant mechanisms include indirect interaction with hydrogen peroxide $\left(\mathrm{H}_{2} \mathrm{O}_{2}\right)$ products (via Fenton chemistry) resulting in nitrous acid $\left(\mathrm{HNO}_{2}\right)$ formation. Another key reactive oxygen species in the vasculature contributing to $\mathrm{NO}$ insufficiency is superoxide $\left(\mathrm{O}_{2}^{-}\right)$which reacts with $\mathrm{NO}$ to form peroxynitrite $\left(\mathrm{OONO}^{-}\right)$. S-nitrosothiols (RSNO) formation via $\mathrm{OONO}^{-}$interaction with thiols, and nitrosyl-heme/S-nitroso-albumin formation represent ways in which NO can be protected from oxidative inactivation, thereby increasing overall bioavailability. 
cells and macrophages are sources of these ROS. NO reacts with $\mathrm{O}_{2}^{-}$. to form peroxynitrite $\left(\mathrm{OONO}^{-}\right)^{55}$ at an almost neardiffusion-limited rate of $6.7 \times 10^{9} \mathrm{M}^{-1} \mathrm{~s}^{-1}$. This rate of peroxynitrite formation exceeds the rate constant for the reduction of superoxide to hydrogen peroxide by superoxide dismutase, the principal antioxidant responsible for $\mathrm{O}_{2}^{-}$metabolism. ${ }^{56}$ Among its deleterious effects are included loss of bioactive NO and direct cytotoxic effects resulting in apoptosis or necrosis. ${ }^{57}$

Through the reduction of $\mathrm{H}_{2} \mathrm{O}_{2}$ via Fenton chemistry, a hydroxyl radical, $\mathrm{OH}$, can react readily with $\mathrm{NO}$, decreasing its bioavailability. ROS in the vessel wall can react with polyunsaturated fatty acid species in the low density lipoprotein (LDL) particle, initiating lipid peroxidation, which results in the formation of oxidized LDL. ${ }^{58}$ Oxidized LDL has been shown to limit NO bioavailability by a number of mechanisms. For example, Chen et al ${ }^{59}$ investigated the role of the L-arginine-NO pathway in oxidized LDL-mediated platelet activation, and found that oxidized LDL decreased L-arginine uptake, eNOS expression, cGMP production, and subsequent NO (nitrite) production.

\section{Nitric oxide synthase regulation}

The activity of NOS is regulated by a number of transcriptional and posttranslational mechanisms as shown in Figure 2. Some modes of regulation are specific to a particular NOS isoform, whereas others are shared between them. Factors regulating NOS activity affect NO bioavailability and, ultimately, target cell function and phenotype. One major factor regulating NOS activity is feedback inhibition by NO itself. NOS isoforms are hemoproteins, readily binding NO to their heme prosthetic groups. ${ }^{60} \mathrm{NO}$ binds reversibly to ferric or ferrous heme proteins within seconds after the initiation of NO synthesis, resulting in temporary eNOS inactivation. ${ }^{60,61}$ These inactive complexes have the ability to reactivate, producing $\mathrm{NO}$ when $\mathrm{NO}$ dissociates from the heme iron. Studies have shown that $70 \%-90 \%$ of iNOS and nNOS are present in their inactive ferrous-NO forms during steady-state catalysis, ${ }^{60,61}$ resulting in NOS activity that is only a fraction of its maximal activity. Ferrous-NO can react with $\mathrm{O}_{2}$ to participate in $\mathrm{NO}$ generation; ferrous-NO complex formation results in $\mathrm{NO}$ synthesis rates proportional to the $\mathrm{O}_{2}$ concentration throughout the physiological range due primarily to NOS-NO complex dissociation, which itself is a function of $\mathrm{O}_{2}$ concentration rather than the intrinsic affinity of the NOS heme iron for $\mathrm{O}_{2} \cdot{ }^{60}$

NOS activity can also be regulated by $\mathrm{BH}_{4}$ levels. $\mathrm{BH}_{4}$ is a critical cofactor required for NO synthesis owing to its ability to couple heme iron reduction to NO synthesis.
Subsaturating levels of $\mathrm{BH}_{4}$ have been shown to result in NOS inhibition by $\mathrm{NO},{ }^{62}$ occurring over several minutes. Possible mechanisms of inactivation include uncoupled $\mathrm{O}_{2}$ reduction to superoxide that occurs in the absence of sufficient $\mathrm{BH}_{4}$, dimer dissociation, ${ }^{62}$ or NO binding to heme. ${ }^{63}$ Dimerization of NOS is essential for its biological activity, and $\mathrm{BH}_{4}$ interacts with residues on both subunits of the dimer and also forms hydrogen bonds with the heme site. Dimerization activates NOS by sequestering heme from solvent, creating favorable conditions for L-arginine and $\mathrm{BH}_{4}$ binding, and also allows electrons from reductase domain flavins to transfer to the oxygenase domain heme. ${ }^{64,65} \mathrm{NO}$ can inhibit expression of NOS, limiting assembly of dimeric NOS by preventing heme insertion and decreasing heme availability. ${ }^{66}$

Another cofactor essential for NO biosynthesis via NOS is the substrate, L-arginine. L-arginine is converted to L-citrulline and NO via a 5-step electron oxidation of the terminal guanidino-nitrogen atom of L-arginine. An experiment of nature leading to L-arginine deficiency also supports the importance of this amino acid in NO and vascular homeostasis. In the genetic disorder, lysinuric protein intolerance, a mutation in the $S L C 7 A 7$ gene leads to impaired L-arginine uptake by cells. ${ }^{67}$ The resulting deficiency of L-arginine transport led to significantly reduced NO synthesis, impaired endothelium-dependent dilation, ${ }^{68}$ and enhanced platelet activation and intravascular coagulation, ${ }^{69}$ highlighting the importance of endogenous L-arginine in NO production and its key vascular actions. ${ }^{70}$

Administration of L-arginine has proven to be protective for endothelial function in animal studies. ${ }^{71}$ Both acute and chronic administration of L-arginine in cholesterol-fed animals results in improvement of endothelium-dependent dilation. ${ }^{72}$ The beneficial effects of $\mathrm{L}$-arginine administration have also been demonstrated in other disease states, such as hypertension, ${ }^{73}$ coronary atherosclerosis,${ }^{74}$ and transgenicknockout sickle mice. ${ }^{75} \mathrm{~L}$-arginine supplementation in hypercholesterolemic rabbits resulted in attenuation of aorta intima/ media thickening and increased eNOS expression compared with controls. ${ }^{76}$ A randomized, double-blind, placebo-controlled study administering oral L-arginine to patients with heart failure for 6 weeks resulted in improved forearm blood flow, increased distances during a 6-minute walk test, as well as improved arterial compliance compared with controls. ${ }^{77}$ Most of the previously mentioned studies showing beneficial effects of L-arginine supplementation were short-term studies. Long-term administration of L-arginine in patients with peripheral artery disease showed the contrary data. Wilson et $\mathrm{al}^{78}$ conducted a randomized clinical trial of oral 


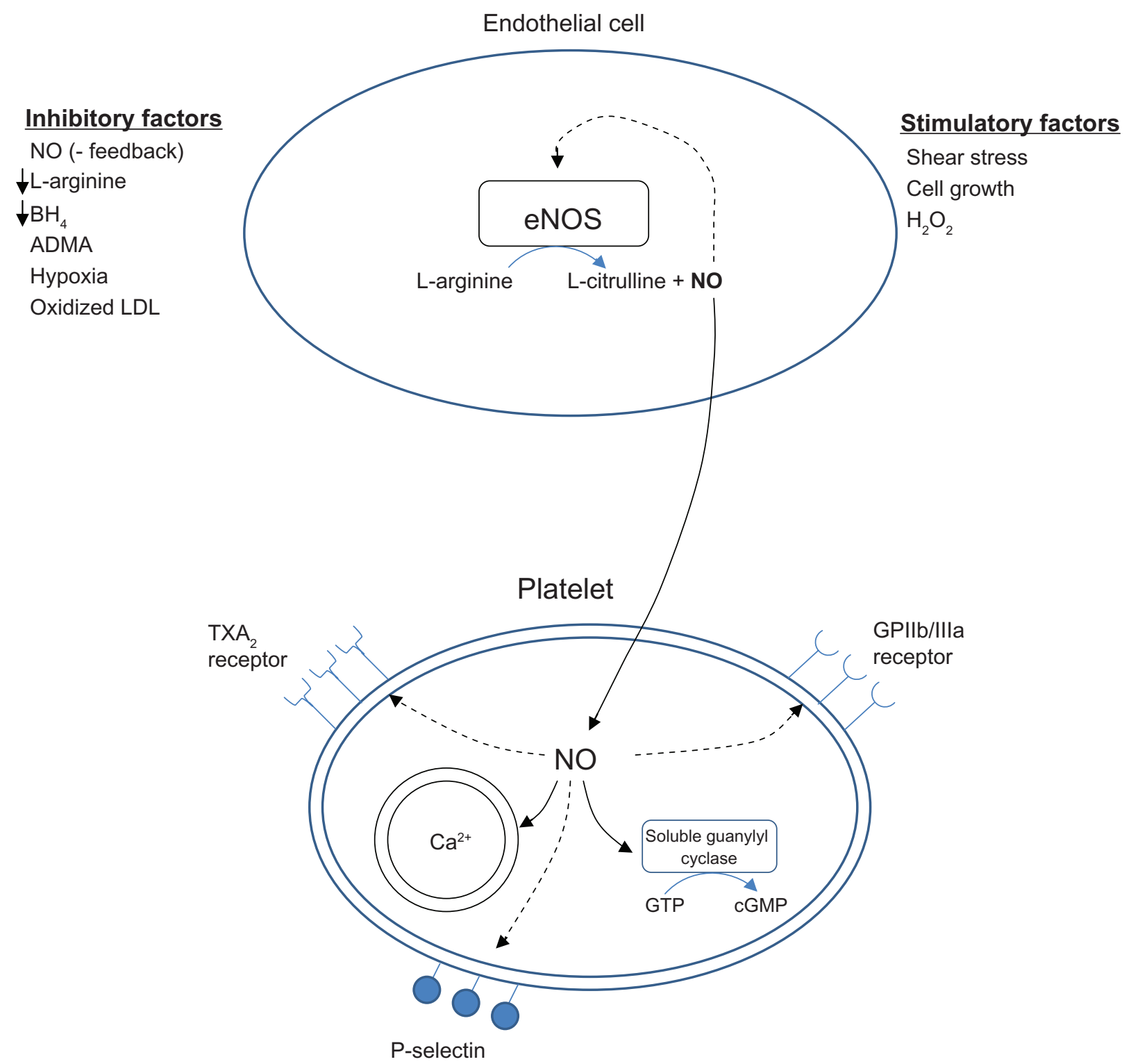

Figure 2 Factors and actions affecting NO and platelet function. Nitric oxide (NO) exerts inhibitory effects (dashed lines) on platelets through a variety of mechanisms. The predominant pathway involves generation of NO from L-arginine by endothelial nitric oxide synthase (eNOS) and cyclic guanosine monophosphate (cGMP) formation via guanylyl cyclase activation by NO. Nitric oxide inhibits platelet activation and aggregation by decreasing intracellular Ca ${ }^{2+}$ concentration, glycoprotein (GP) IIB/Illa expression, and platelet association with fibrinogen. cGMP, formed from NO's catalytic effect on guanylyl cyclase, also inhibits platelets by decreasing thromboxane $A_{2}$ expression as well as expression of the platelet surface adhesion molecule, P-selectin. Endothelial NOS activity is regulated by several transcriptional, posttranslational, and physiological factors that either result in inactivation or upregulation, ultimately affecting NO bioavailability. Factors decreasing eNOS (dashed lines) activity include NO itself, via negative feedback, reduced substrate and/or cofactor bioavailability, hypoxia, and oxidized low density lipoprotein (LDL). By contrast, laminar shear stress, cell growth, and $\mathrm{H}_{2} \mathrm{O}_{2}$ have been shown to increase eNOS activity (solid lines), cGMP formation, and bioavailable NO.

L-arginine vs placebo for 6 months in patients with intermittent claudication due to peripheral artery disease. They found that long-term L-arginine supplementation did not increase NO synthesis or improve vascular reactivity. ${ }^{78}$ In another clinical study involving patients with stable coronary heart disease, L-arginine supplementation failed to show any significant improvement of endothelium-dependent vasodilation or blood flow as compared with placebo. ${ }^{79}$ L-arginine supplementation has also been shown to have no significant effect on endothelial function, blood flow, markers for oxidative stress, or exercise performance in patients with coronary heart disease and stenosis ${ }^{80}$ as well as no benefit in patients with coronary artery disease after the onset of myocardial infarction with respect to death, reinfarction, or recurrent myocardial ischemia. ${ }^{81}$ The mechanism by which L-arginine administration exerts its beneficial effects in various disease states is unclear; however, future benefits occurring via the enhancement of vascular NO synthesis has been supported 
by corresponding upregulation of the NO-cGMP pathway in endothelial cells of the myocardium. ${ }^{82}$

In addition to limited cofactor availability affecting eNOS activity and NO synthesis, a naturally occurring inhibitor, asymmetric dimethylarginine (ADMA), was first identified in $1992 .{ }^{83}$ ADMA is synthesized by methylation of arginine residues via $\mathrm{N}$-methyltransferases, which utilize S-adenosylmethionine as a methyl group donor. It is released when the methylated arginine residues are degraded into their amino acid components during hydrolytic protein turnover. ${ }^{84}$ The physiological effects of ADMA were first characterized in vascular rings where ADMA inhibited NOS resulting in decreased NO synthesis and vasoconstriction. ${ }^{83}$ Plasma ADMA concentrations are elevated in many disease states, including hypercholesterolemia,${ }^{85}$ hyperhomocysteinemia, ${ }^{86}$ hypertension, ${ }^{87}$ pulmonary hypertension, ${ }^{88}$ stroke, ${ }^{89}$ and diabetes mellitus. ${ }^{90} \mathrm{~A}$ recent study by Ding et $\mathrm{a}^{91}$ identified a novel 4-nucleotide deletion/insertion variant in the dimethylarginine dimethylaminohydrolase I ( $D D A H 1)$ gene, an important gene in the major pathway for ADMA clearance, associated with increased susceptibility to thrombotic stroke and coronary heart disease. Overexpression of DDAH1 has been shown to protect against cerebral arteriole hypertrophy and to improve vascular smooth muscle function. ${ }^{92}$ In a study investigating the effects of ADMA on shear stress-dependent dilation of skeletal muscle arterioles, Toth et $\mathrm{a} \mathrm{l}^{93}$ showed that ADMA inhibited shear stress-induced NO release and vasodilation, and, instead, stimulated $\mathrm{O}_{2}^{-\cdot}$ release, favoring the development of increased shear stress, increased vascular resistance, and, ultimately, hypertension.

The association between plasma ADMA concentration and endothelial dysfunction contributing to cardiovascular disease has lead to its emerging as a novel risk factor and potential pharmacotherapeutic target. Clinical studies involving L-arginine supplementation in hypercholesterolemic subjects have shown improved endothelial function, ${ }^{94}$ improved vasomotor responses to methacholine, ${ }^{95}$ and improved flowmediated dilation ${ }^{96}$ in the brachial artery. Studies involving L-arginine supplementation in subjects with arterial hypertension have also shown increases in forearm blood flow, ${ }^{77}$ improvement in coronary small-vessel endothelial function, ${ }^{97}$ and decreased blood pressure via increased NO production. ${ }^{98}$

In addition to posttranslational mechanisms regulating NOS activity, there are many transcriptional and posttranscriptional regulators of the enzyme. Posttrascriptional regulators of eNOS include phosphorylation by several kinases regulating protein-protein interactions and the avail- ability of cofactors and substrates, ${ }^{99}$ localization of eNOS to the caveolae, and dissociation from caveolin- $1 .{ }^{100}$ Other posttranslational modifications regulating eNOS expression include myristoylation and palmitoylation, which are required for the targeting of eNOS to the caveolae. ${ }^{101,102}$

Several physiological and pathophysiological stimuli have been indentified that affect eNOS mRNA expression and stability. Stimuli shown to increase eNOS expression include shear stress, cell growth, and hydrogen peroxide. By contrast, hypoxia and oxidized LDL can decrease eNOS expression. One of the more potent regulators of eNOS expression is laminar shear stress. Both in vivo ${ }^{103}$ and in vitro ${ }^{104,105}$ studies have shown an upregulation in eNOS expression due to shear stress. Weber et a $1^{106}$ conducted in vitro experiments using bovine aortic endothelial cells and found that shear stress increased expression of eNOS mRNA with long poly(A) tails resulting in a 3-fold increase in half-life compared with cells not exposed to shear (ie, cultured under static conditions). Their results support the concept that shear stress modulates eNOS mRNA stability and translation via increased 3 -adenylation due to a dose-dependent effect of shear on eNOS polyadenylation, also observed in vivo, ${ }^{107}$ and shown to be dependent on the duration of shear stress. Laminar shear stress resulted in an early increase in eNOS mRNA expression and a sustained stabilization of eNOS mRNA, as evidenced by a 4-fold to 5 -fold increase in transcription and an increase in mRNA half-life by more than 3-fold compared with cells cultured under static conditions. ${ }^{108}$ Davis et a ${ }^{108}$ identified two pathways involving c-src that lead to an increase in eNOS mRNA transcription and mRNA stability. The increase in eNOS mRNA transcription involved the Raf, Ras, and ERK $1 / 2$ pathway, whereas the stabilization of eNOS in response to shear stress was completely abrogated by the c-src inhibitor PP1, but not altered by Ras or ERK inhibition, supporting the existence of separate pathways responsible for the increase in transcription and for mRNA stabilization.

More recent studies identified miR-21 as a regulator of eNOS activity and apoptosis in human umbilical vein endothelial cells (HUVEC). MicroRNAs are short RNA molecules averaging 22 nucleotides that bind to complementary sequences in the 3 '-untranslated region (UTR) of mRNA transcripts, leading to posttranscriptional regulation (degradation of mRNAs) of genes involved in differentiation, proliferation, and apoptosis. Through the utilization of a TaqMan low density array and qRT-PCR, miR-21 was shown to be increased 5.2-fold in HUVECs exposed to unidirectional shear stress compared with cells grown under static conditions. HUVECs overexpressing miR-21 had 
decreased apoptosis and increased eNOS phosphorylation and NO production. ${ }^{109}$ miR-21 also suppressed phosphatase and tensin (PTEN), which is a tumor suppressor gene, and has been shown to play an important role in regulating apoptosis via antagonism of the PI3K/Akt pathway. ${ }^{110}$ The authors concluded that miR-21 overexpression in HUVECs involves regulation of PTEN expression and subsequent changes in the PI3K/Akt/eNOS pathway. ${ }^{109}$

Cell growth has also been shown to be a potent stimulus for eNOS expression, both in vitro ${ }^{111}$ and in vivo. ${ }^{112}$ In vitro studies using bovine aortic endothelial cells (BAECs) revealed a 3-fold increase in eNOS protein level, a 6-fold increase in mRNA expression, and a 3-fold increase in eNOS activity in proliferating cells compared with confluent cells. ${ }^{111}$ The authors concluded that these results were due either to an increase in transcription or a decrease in degradation of eNOS mRNA. In a follow-up study, Searles et $\mathrm{al}^{113}$ investigated the factors responsible for changes in eNOS expression during cell proliferation. Using BAECs, they showed steady-state eNOS mRNA levels to be 4-fold higher in proliferating cells compared with confluent cells. A nuclear run-on analysis was performed to determine whether or not this was due to a change in transcription. The intensity of the bands for eNOS nascent transcripts was identical between proliferating and confluent cells, thereby providing evidence for growthinduced regulation of eNOS expression modulated by posttranscriptional mechanisms. By contrast, they observed a 3 -fold increase in half-life in proliferating cells compared with confluent cells. Ultraviolet-crosslinking analysis revealed a 51-kDa protein expressed 3-fold higher in confluent cells compared with proliferating cells. This cytosolic protein was found to bind to a 43-nt cis-element in the proximal $3{ }^{\prime}$-UTR resulting in destabilization of eNOS mRNA. ${ }^{113}$

Endothelial NO activity has also been shown to be regulated by ROS. Hydrogen peroxide, in particular, induces both an elevation of eNOS protein expression and enzyme activity. Studies have shown that adding $\mathrm{H}_{2} \mathrm{O}_{2}$ to endothelial cells stimulates eNOS activation by PI3-kinase-Akt-mediated phosphorylation of Ser1177 on eNOS. ${ }^{114}$ Drummond et $\mathrm{al}^{115}$ performed nuclear run-on and 5,6-dichloro-1- $\beta$-Dribofuranosylbenzimidazole case studies to show a 3-fold increase in eNOS transcription and a 2.8-fold increase in eNOS half-life in cells exposed to $\mathrm{H}_{2} \mathrm{O}_{2}$. A subsequent study revealed that the induction of eNOS expression by $\mathrm{H}_{2} \mathrm{O}_{2}$ was $\mathrm{Ca}^{2+}$-dependent. Immunocytochemical staining of BAECs revealed expression of $\mathrm{Ca}^{2+} /$ calmodulin-dependent protein kinase II (CaM kinase II), and an in-gel kinase assay showed $\mathrm{H}_{2} \mathrm{O}_{2}$-induced autophosphorylation of CaM kinase II, resulting in increased eNOS activity. Cai et al ${ }^{116}$ were able to show that $\mathrm{H}_{2} \mathrm{O}_{2}$-induced activation of eNOS was dependent on the CaM kinase II/Janus kinase (JNK) 2 pathway. Hydrogen peroxide produced under shear stress has been shown to be regulated by PKC delta. Kumar et al ${ }^{117}$ investigated the mechanism by which shear stress can stimulate eNOS activity via PI3 kinase/Akt signaling and phosphorylation of Ser1177. They found that shear stress decreased PKC delta activity, attenuating catalase activity and increasing $\mathrm{H}_{2} \mathrm{O}_{2}$ signaling, resulting in increased eNOS phosphorylation at Ser1177 and NO synthesis. ${ }^{117}$ A recent study by Tian et al ${ }^{118}$ investigated how $\mathrm{H}_{2} \mathrm{O}_{2}$ affects $\mathrm{NO}$ activity when endothelial cells are subjected to shear stress. Using a small interfering RNA for caveolin-1, they showed decreased eNOS localization to the plasma membrane as well as impairment of increases in NO in BAECs. Caveolin-1 enhances eNOS transport to the plasma membrane and appears to be involved in priming eNOS for activation under conditions of shear stress. ${ }^{118}$

Although factors such as shear stress, cell proliferation, and $\mathrm{H}_{2} \mathrm{O}_{2}$ have been found to increase both eNOS expression and stability, hypoxia has been associated with both upregulation and down-regulation of eNOS expression via transcriptional and posttranscriptional mechanisms. ${ }^{119-122}$ In response to hypoxia, the systemic arteries will dilate, allowing more blood to be delivered to peripheral tissues, whereas vasoconstriction will take place in the pulmonary system resulting in higher pulmonary pressures. This same trend has been shown for eNOS expression in rats exposed to hypoxia. Rats subjected to $10 \%$ oxygen for 12 hours, 48 hours, or 7 days showed an $80 \%$ decrease in eNOS protein expression as well as eNOS mRNA expression compared with normoxic controls. ${ }^{119}$ Exposure to hypoxia also resulted in impaired capacity of aortic segments to generate cGMP in response to stimulation by acetylcholine. Comparison of eNOS expression in the left and right lungs of normoxic and chronically hypoxic rats resulted in a decrease in eNOS protein expression $(32 \% \pm 7 \%)$ and eNOS mRNA expression $(54 \% \pm 13 \%)$ in hypoxic lungs compared with the normoxic lung from the same rat. ${ }^{120}$ Thus, not only are there regional differences in eNOS expression in the setting of hypoxia, but the onset or duration of hypoxia may also affect eNOS expression. In lung biopsies of infants with pulmonary hypertension secondary to cardiac abnormalities (early stage of pulmonary hypertension), eNOS expression was found to be significantly increased in pulmonary vascular endothelial cells. ${ }^{121}$ This increase in eNOS expression in early stages of pulmonary vascular disease may represent a compensatory mechanism to rising pulmonary pressures. However, in the 
setting of chronic pulmonary hypertension, there is reduced eNOS expression. ${ }^{122}$

Endothelial NOS activity is not always simply overexpressed or inhibited by certain physiological or pathophysiological stimuli. As is the case with hypoxia, where regional differences and onset/duration of disease can affect eNOS expression, oxidized LDL has been shown to elicit both stimulatory and inhibitory responses in eNOS expression. Liao et al ${ }^{123}$ treated human saphenous vein endothelial cells with increasing concentrations of native or oxidized LDL and found that oxidized LDL resulted in a time-dependent decrease in eNOS mRNA expression. This decrease in eNOS mRNA expression coincided with a $56 \%$ decrease in NOS activity. Nuclear run-on studies revealed the complex nature of eNOS regulation by oxidized LDL. During the first 6 hours of treatment, eNOS expression was decreased by $25 \%$, followed by a 2.2 -fold increase in the subsequent 18 hours. The results of this study indicate that oxidized LDL regulates eNOS expression through a combination of early transcriptional inhibition and mRNA destabilization.

\section{Vascular diseases and nitric oxide}

\section{Atherosclerosis and thrombosis}

In addition to promoting endothelial dysfunction, NO insufficiency has been shown to increase atherosclerotic burden in vivo. Under normal conditions, NO exerts atheroprotective effects through several pathways, including the reduction of endothelial cell apoptosis and activation, via inhibition of nuclear factor-kappa factor (NF- $\mathrm{\kappa B})$ and inflammatory gene expression. ${ }^{124}$ Another way in which NO prevents atherogenesis is via the attenuation of leukocyte-endothelial cell adhesive interactions. ${ }^{125} \mathrm{BH}_{4}$ deficiency, which is commonplace in vascular disease, has been linked to eNOS uncoupling in the vasculature, resulting in $\mathrm{O}_{2}^{--}$production and NO insufficiency. A more recent study by Takaya et al ${ }^{126}$ highlighted the importance of $\mathrm{BH}_{4}$ availability in preventing eNOS uncoupling-induced atherosclerotic lesion progression. The authors compared atherosclerotic lesion progression between apolipoprotein $\mathrm{E}$ knockout (ApoE-KO)/eNOS-Tg mice treated with vitamin $\mathrm{C}$ and ApoE-KO mice crossed with mice overexpressing eNOS (eNOS-Tg) with mice overexpressing GTP-cyclohydrolase I (GCH-Tg) to produce ApoE-KO/eNOS-Tg/GCH-Tg mice. Atherosclerotic formation was increased in the ApoE-KO/ eNOS-Tg mice compared with ApoE-KO mice. This finding was attributed to uncoupled eNOS-superoxide production and was reversed by overexpressing GTP-cyclohydrolase I, the rate-limiting enzyme in $\mathrm{BH}_{4}$ synthesis. ${ }^{126}$ Endothelial dysfunction in hypercholesterolemia has been implicated in atherosclerosis progression. Several studies have shown a decrease of eNOS activity and expression, ${ }^{127,128}$ as well as its reversal with L-arginine supplementation ${ }^{129,130}$ in hypercholesterolemic models.

NO insufficiency, eNOS deficiency, ${ }^{131}$ and a deficiency of the extracellular antioxidant enzyme plasma glutathione peroxidase (GPx-3) in patients with vascular disease and stroke represent further evidence of the prothrombotic consequence of NO insufficiency in vivo. The first direct evidence that an arterial thrombotic disorder can derive from NO insufficiency stems from a study conducted by Freedman et al ${ }^{132}$ analyzing platelet inhibition by NO in 2 brothers with a cerebral thrombotic disorder of unknown etiology. The patients were found to have hyperreactive platelets, a 3-fold increase in plasma $\mathrm{H}_{2} \mathrm{O}_{2}$, and decreased GPx-3 activity. GPx-3 is an enzyme that protects cells from oxidative damage via the reduction of hydrogen peroxide and lipid hydroperoxides. GPx-3 is produced primarily in the renal promixal tubules and is the only isoform in the GPx family that is found in the extracellular space. During platelet activation, specifically, activation of the second messenger cascade and the cytoskeletal changes that occur, ROS are generated. ${ }^{133}$ Hydrogen peroxide production as a result of collage-stimulated platelet activation has been shown to reach concentrations up to $1 \mathrm{mM} .{ }^{134} \mathrm{GPx}-3$ maintains NO bioavailability by preventing the accumulation of ROS like $\mathrm{H}_{2} \mathrm{O}_{2}$, allowing $\mathrm{NO}$ to exert an inhibitory effect on platelets and preventing platelet-dependent thrombosis. Through platelet/plasma mixing experiments, it was determined that NO bioavailability was too low to limit platelet activation in patient plasma. After glutathione peroxidase was exogenously added to the patient plasma, the inhibitory effects of $\mathrm{NO}$ were restored. We concluded that decreased levels of GPx-3 resulted in increase ROS flux, limiting the ability of NO to inhibit further platelet recruitment to the growing platelet thrombus (which is partly due to plateletderived $\mathrm{NO}^{135}$ ), resulting in a prothrombotic state. More recent studies have demonstrated an association between decreased GPx-3 activity in both arterial ischemic stroke ${ }^{136}$ and cerebral venous thrombosis ${ }^{137}$ patients.

\section{Hypertension}

Endothelial dysfunction in hypertension and diabetes mellitus appears to be due, in part, to an imbalance in ROS generation and a decrease in NO bioavailability. This decrease in NO bioavailability contributes to endothelial dysfunction, a common property in essential hypertension ${ }^{138-140}$ and diabetes mellitus. ${ }^{141,142}$ Endothelial NOS plays a prominent 
role in regulating NO bioavailability, which contributes to endothelial function or the lack thereof, in various vascular disease states. In most situations in which endothelial dysfunction occurs as a result of increased oxidative stress, eNOS expression is upregulated rather than decreased. ${ }^{143,144}$ This paradoxical increase in eNOS expression is likely due to increased $\mathrm{H}_{2} \mathrm{O}_{2}$ production by the endothelium, which upregulates eNOS via the PI3/Akt pathway. Upregulation of eNOS expression in the setting of endothelial dysfunction shows that this increase in NO synthesis may not be sufficient to overcome the deleterious effects or other factors that limit and decrease overall NO bioavailability.

Several studies have shown that eNOS uncoupling due to insufficient levels of the cofactor $\mathrm{BH}_{4}$ can shift eNOS activity away from converting L-arginine to L-citrulline and $\mathrm{NO}$ production, toward generating $\mathrm{O}_{2}^{-}$via reduction of molecular oxygen. ${ }^{145,146}$ Although several studies have shown that L-arginine supplementation improves endothelial dysfunction, ${ }^{72,147,148}$ physiological concentrations in plasma $(\sim 100 \mu \mathrm{M})^{149}$ far exceed the $K_{\mathrm{m}}$ of eNOS for L-arginine $(\sim 3 \mu \mathrm{M}),{ }^{150,151}$ making substrate insufficiency an unlikely cause of eNOS uncoupling. As previously mentioned, $\mathrm{BH}_{4}$ plays a critical role in eNOS activation that binds to heme and is involved in the electron transport-mediated release of $\mathrm{NO}$ and L-citrulline. Under conditions in which $\mathrm{BH}_{4}$ is limited, eNOS cannot transfer electrons efficiently and, instead, reduces molecular oxygen resulting in $\mathrm{O}_{2}^{-}$production. One possible cause of $\mathrm{BH}_{4}$ depletion may be attributed to its reactivity with $\mathrm{OONO}^{-}$. Peroxynitrite is readily formed when NO reacts with $\mathrm{O}_{2}^{-}$, which, in turn, can readily oxidize $\mathrm{BH}_{4}$ to the $\mathrm{BH}_{3}$ radical, resulting in eNOS uncoupling. Oxidative degradation of $\mathrm{BH}_{4}$ by $\mathrm{H}_{2} \mathrm{O}_{2}$ and $\mathrm{OONO}^{-}$leading to the formation of 7,8-dihydro- L-biopterin, effectively competing for eNOS $\mathrm{BH}_{4}$ binding sites, also results in eNOS uncoupling.

A major source of ROS found in hypertension can be attributed to activity of the NADPH-oxidases. NADPHoxidase is a multisubunit enzyme that catalyzes the production of $\mathrm{O}_{2}^{-}$by the 1-electron reduction of $\mathrm{O}_{2}$ using NADPH as the electron donor. An increase in NADPH-oxidase activity has been implicated with regulating vascular tone directly or indirectly by decreasing NO bioavailability through $\mathrm{O}_{2}^{-}$. production. ${ }^{152,153}$ Several studies have shown an increase in NADPH-oxidase-dependent $\mathrm{O}_{2}^{-}$production resulting in decreased NO bioavailability. ${ }^{154,155}$ Superoxide dismutase, an antioxidant responsible for neutralization of $\mathrm{O}_{2}^{-}$, was recently shown to prevent NADPH-oxidase-induced oxidative stress in both the early stages of diabetes mellitus and hypertension, ${ }^{156}$ providing further evidence for redox imbalance contributing to endothelial dysfunction in these disorders.

\section{Diabetes mellitus}

As with hypertension, ROS generation and redox imbalance play a causative role in endothelial dysfunction in diabetes mellitus. Increased $\mathrm{O}_{2}^{-}$levels have been reported in diabetic rats $^{157,158}$ as well as in diabetic hypertensive patients. ${ }^{159}$ Hyperglycemia increases $\mathrm{O}_{2}^{-}$generation in endothelial cells. ${ }^{160}$ Possible mechanisms contributing to ROS generation under hyperglycemic conditions involve direct effects of glucose and free fatty acids on endothelial ROS production, as well as via the generation of advanced glycation end (AGE)-products.

The activation of NADPH-oxidase has been implicated as a source of increased ROS formation in endothelial cells exposed to hyperglycemia ${ }^{161}$ as well as in hyperglycemic rats. ${ }^{162}$ NADPH-oxidase activation appears to occur via increased diacylglycerol-mediated activation of $\mathrm{PKC}^{161}$ and PI3-kinase-dependent activation of PKC, ${ }^{163}$ both of which result in ROS production. Free fatty acids also stimulate ROS formation in endothelial cells ${ }^{164,165}$ and appear to be associated with PKC activation. ${ }^{161}$ Recent studies have shown a synergistic activation of glucose-6-phosphate dehydrogenase, the rate limiting enzyme in the pentose phosphate pathway, and NADPH-oxidase resulting in increased $\mathrm{O}_{2}^{-}$. generation in type 2 diabetic rats. ${ }^{166,162}$ AGE-products are formed as a result of nonenzymatic glycation and oxidation of proteins, lipids, and polynucleotides. The receptor for advanced glycation end-products (RAGE) is a pattern recognition receptor that interacts with a variety of ligands. RAGE signaling includes the activation of NF- $\kappa \mathrm{B}$, which is associated with inflammation. ${ }^{167}$ In vascular endothelial cells and monocytes, RAGE activation results in ROS formation via NADPHoxidase activation. Although there are many possible causes of endothelial dysfunction in the setting of hypertension and diabetes, ROS generation, specifically $\mathrm{O}_{2}^{-}$, appears regulated principally by NADPH-oxidase activation.

\section{Pharmacotherapies and vascular nitric oxide \\ Effects of statins on nitric oxide}

3-Hydroxy-3-methylglutaryl coenzyme A (HMG-CoA) reductase inhibitors (statins) are accepted as first-line agents for the prevention of cardiovascular diseases associated with atherosclerosis. Statins lower serum cholesterol by inhibiting the reduction of HMG-CoA to mevalonate, the rate-limiting step of liver cholesterol biosynthesis. ${ }^{168}$ Statins 
have been shown to reduce adverse cardiovascular events independent of the reduction of lowered serum cholesterol levels, suggesting additional beneficial effects of the drugs. These cholesterol-independent, pleiotropic effects of statins include improvement in endothelial function, stability of atherosclerotic plaques, and a decrease in oxidative stress and inflammation. ${ }^{169}$ In endothelial cells, inactivation of RhoA by statins results in increased NO biosynthesis through increased expression of eNOS. ${ }^{170}$ Recently, Nohria et al ${ }^{171}$ demonstrated that high-dose atorvastatin inhibits the Rho/Rho-associated kinase pathway in patients with atherosclerosis, independent of cholesterol reduction.

Several studies have investigated the possible mechanisms by which statins increase NO bioavailability. One such study by Laufs et al ${ }^{172}$ investigated whether statins can directly upregulate eNOS activity independent of a decrease in serum cholesterol levels. Human saphenous vein endothelial cells treated with oxidized-LDL resulted in decreased eNOS mRNA and protein levels $(91 \% \pm 4 \%$ and $67 \% \pm 8 \%$ ) after 72 hours. ${ }^{172}$ Treatment with either simvastatin or lovastatin resulted in increased eNOS expression by almost 4-fold. Actinomycin treatment revealed that statins also increased the half-life of eNOS mRNA, supporting the concept that upregulation of eNOS by statins occurs via a posttranscriptional mechanism. Other studies showed that statins increased eNOS activity via activation of the PI3/Akt kinase pathway, resulting in upregulation of eNOS, increased cGMP production, and NO biosynthesis. ${ }^{173,174}$

Another mechanism by which statins restore endothelial function is through the inhibition of NADPH oxidase activity and uncoupled eNOS-dependent $\mathrm{O}_{2}^{-}$. production. ${ }^{175,176}$ Cholesterol is a large component of caveolae, which constitute plasma membrane microdomains and are ubiquitously present in endothelial cells. ${ }^{177}$ Caveolin-1 is a 22 $\mathrm{kDa}$ protein constituent of caveolae which acts as a scaffolding protein that can modulate signaling of proteins and mediate transcytosis, transferring molecules from the lumen of blood vessels to the subendothelial space. Caveolae have been shown to be involved in the regulation of eNOS, which targets to endothelial caveolae via $\mathrm{N}$-terminal myristoylation and plamitoylation, forming an inhibitory complex, that renders the enzyme inactive. ${ }^{178}$ This inhibitory complex can be reversed through increased $\mathrm{Ca}^{2+}$ concentrations, leading to $\mathrm{Ca}^{2+}$-calmodulin binding and caveolin displacement of eNOS. ${ }^{179}$ A recent study by Suh et al showed that rosuvastatin improved endothelial dysfunction in spontaneously hypertensive rats: the statin resulted in increased $\mathrm{NO}_{x}$ levels, phosphorylation of eNOS at Ser1177, and decreased caveolin-1 expression compared with controls. ${ }^{180}$

\section{Nitrovasodilators and vascular nitric oxide}

Nitrovasodilators have long been used in clinical settings to treat angina pectoris. Even though the physiological effects of nitrate administration is undeniably beneficial, the mechanisms through which it exerts its effects on the endothelium and the heart are not fully understood. A number of studies have implicated several enzymes, such as glutathione S-transferase, ${ }^{181,182}$ oxidoreductases, ${ }^{183}$ and mitochondrial aldehyde dehydrogenase, ${ }^{184}$ in the bioactivation and conversion of nitroglycerin to NO. Despite the extensive number of studies conducted, none have been able to explain the observation that maximal nitroglycerin-induced vasorelaxation occurs within minutes of administration, ${ }^{185}$ whereas NO produced from nitroglycerin bioactivation takes over an hour. ${ }^{186}$ Bonini et al recently investigated the possible role for eNOS-mediated vasodilation in response to nitroglycerin administration. In their study, the authors showed a decrease in systolic and diastolic pressures immediately after sublingual nitroglycerin administration in rats. Treatment with NOS inhibitors, aminoguanidine and L- $\mathrm{N}^{5}$-(1-iminoethyl) ornithine dihydrochloride, inhibited average diastolic arterial pressures and aortic ring relaxation compared with controls. ${ }^{187}$ They also showed a time course of nitroglycerininduced eNOS phosphorylation in HUVEC cells, which resulted in peak Ser1177-phosphorylation 5 minutes after treatment. Through their study, they suggested that eNOS modulation by nitroglycerin is involved in the immediate effects following nitroglycerin administration.

\section{Conclusion}

NO plays a versatile role in the vasculature, maintaining vascular tone, inhibiting or reversing platelet activity, and preventing endothelial dysfunction often seen in vascular disease states. This highly reactive molecule contributes to vascular hemostasis through a variety of different pathways, with the classical signaling heme group-binding reaction leading to activation of soluble guanylyl cyclase to produce cGMP as a central mechanism. Not surprisingly, NO exerts its inhibitory effects on platelets primarily, but not entirely, through cGMP generation, which, in turn, decreases intracellular $\mathrm{Ca}^{2+}$ concentration, GPIIb/IIIa expression, platelet fibrinogen binding, and platelet surface P-selectin expression. In the vasculature, an increase in ROS leading to NO insufficiency defines the pathobiological state of oxidant stress. Oxidant 
stress can arise from pathophysiological stimulation of enzymatic sources and can result in a perturbation of normal endothelial and platelet function. Although NO inactivation is primarily due to deleterious interactions with ROS within the vasculature, other factors limiting cofactor or substrate bioavailability may result in eNOS uncoupling, resulting in decreased NO generation. Nevertheless, despite the increasing amount of information acquired since the discovery of endogenous NO 3 decades ago, many questions remain about the versatile nature of NO itself, and the complex interactions in which it is involved. With respect to potential new therapies intended to treat disease states, such as hypertension, diabetes mellitus, and atherothrombosis, associated with NO insufficiency, more studies, both basic and clinical, are clearly needed to elucidate the complex role NO plays in treating or preventing these common disorders.

\section{Disclosure}

The authors report no conflicts of interest in this work.

\section{References}

1. Furchgott RF, Zawadzki JV. The obligatory role of endothelial cells in the relaxation of arterial smooth muscle by acetylcholine. Nature. 1980;288(5789):373-376.

2. Palmer RM, Ferrige AG, Moncada S. Nitric oxide release accounts for the biological activity of endothelium-derived relaxing factor. Nature. 1987;327(6122):524-526.

3. Bolotina VM, Najibi S, Palacino JJ, Pagano PJ, Cohen RA. Nitric oxide directly activates calcium-dependent potassium channels in vascular smooth muscle. Nature. 1994;368(6474):850-853.

4. Horowitz A, Menice CB, Laporte R, Morgan KG. Mechanisms of smooth muscle contraction. Physiol Rev. 1996;76(4):967-1003.

5. Stamler JS, Loh E, Roddy MA, Currie KE, Creager MA. Nitric oxide regulates basal systemic and pulmonary vascular resistance in healthy humans. Circulation. 1994;89(5):2035-2040.

6. Howard TD, Giles WH, Xu J, et al. Promoter polymorphisms in the nitric oxide synthase 3 gene are associated with ischemic stroke susceptibility in young black women. Stroke. 2005;36(9):1848-1851.

7. Loscalzo J. Nitric oxide insufficiency, platelet activation, and arterial thrombosis. Circ Res. 2001;88(8):756-762.

8. Smith DT, Hoetzer GL, Greiner JJ, Stauffer BL, DeSouza CA. Endothelial release of tissue-type plasminogen activator in the human forearm: role of nitric oxide. J Cardiovasc Pharmacol. 2003;42(2): 311-314.

9. Pretorius M, Brown NJ. Endogenous nitric oxide contributes to bradykinin-stimulated glucose uptake but attenuates vascular tissuetype plasminogen activator release. J Pharmacol Exp Ther. 332(1): 291-297.

10. Giannarelli C, De Negri F, Virdis A, et al. Nitric oxide modulates tissue plasminogen activator release in normotensive subjects and hypertensive patients. Hypertension. 2007;49(4):878-884.

11. Ware JA, Heistad DD. Seminars in medicine of the Beth Israel Hospital, Boston. Platelet-endothelium interactions. $N$ Engl J Med. 1993;328(9):628-635.

12. Battinelli EM, Loscalzo J. Nitric Oxide and Platelet-Mediated Hemostasis. Totowa, NJ: Humana; 2000:123-138.

13. Moncada S, Higgs EA, Vane JR. Human arterial and venous tissues generate prostacyclin (prostaglandin $\mathrm{x}$ ), a potent inhibitor of platelet aggregation. Lancet. 1977;1(8001):18-20.
14. Aszodi A, Pfeifer A, Ahmad M, et al. The vasodilator-stimulated phosphoprotein (VASP) is involved in cGMP- and cAMP-mediated inhibition of agonist-induced platelet aggregation, but is dispensable for smooth muscle function. EMBO J. 1999;18(1):37-48.

15. Gayle RB 3rd, Maliszewski CR, Gimpel SD, et al. Inhibition of platelet function by recombinant soluble ecto-ADPase/CD39. J Clin Invest. 1998;101(9):1851-1859.

16. Wang GR, Zhu Y, Halushka PV, Lincoln TM, Mendelsohn ME. Mechanism of platelet inhibition by nitric oxide: in vivo phosphorylation of thromboxane receptor by cyclic GMP-dependent protein kinase. Proc Natl Acad Sci U S A. 1998;95(9):4888-4893.

17. Kroll MH, Schafer AI. Biochemical mechanisms of platelet activation. Blood. 1989;74(4):1181-1195.

18. Niki I, Hidaka H. Roles of intracellular $\mathrm{Ca}^{+}$receptors in the pancreatic beta-cell in insulin secretion. Mol Cell Biochem. 1999; 190(1-2):119-124.

19. Nishikawa M, Tanaka T, Hidaka H. Ca2 ${ }^{+}$-calmodulin-dependent phosphorylation and platelet secretion. Nature. 1980;287(5785):863-865.

20. Lokeshwar VB, Bourguignon LY. The involvement of $\mathrm{Ca}^{+}{ }^{+}$and myosin light chain kinase in collagen-induced platelet activation. Cell Biol Int Rep. 1992;16(9):883-897.

21. Neumuller O, Hoffmeister M, Babica J, Prelle C, Gegenbauer K, Smolenski AP. Synaptotagmin-like protein 1 interacts with the GTPaseactivating protein Rap1GAP2 and regulates dense granule secretion in platelets. Blood. 2009;114(7):1396-1404.

22. Trepakova ES, Cohen RA, Bolotina VM. Nitric oxide inhibits capacitative cation influx in human platelets by promoting sarcoplasmic/ endoplasmic reticulum $\mathrm{Ca} 2^{+}$-ATPase-dependent refilling of $\mathrm{Ca}_{2}^{+}$stores. Circ Res. 1999;84(2):201-209.

23. Cornwell TL, Pryzwansky KB, Wyatt TA, Lincoln TM. Regulation of sarcoplasmic reticulum protein phosphorylation by localized cyclic GMP-dependent protein kinase in vascular smooth muscle cells. Mol Pharmacol. 1991;40(6):923-931.

24. Pigazzi A, Heydrick S, Folli F, Benoit S, Michelson A, Loscalzo J. Nitric oxide inhibits thrombin receptor-activating peptide-induced phosphoinositide 3-kinase activity in human platelets. J Biol Chem. 1999;274(20):14368-14375.

25. Mendelsohn ME, O’Neill S, George D, Loscalzo J. Inhibition of fibrinogen binding to human platelets by S-nitroso-N-acetylcysteine. J Biol Chem. 1990;265(31):19028-19034.

26. Murohara T, Parkinson SJ, Waldman SA, Lefer AM. Inhibition of nitric oxide biosynthesis promotes $\mathrm{P}$-selectin expression in platelets. Role of protein kinase C. Arterioscler Thromb Vasc Biol. 1995;15(11):2068-2075.

27. Battinelli E, Loscalzo J. Nitric oxide induces apoptosis in megakaryocytic cell lines. Blood. 2000;95(11):3451-3459.

28. Battinelli E, Willoughby SR, Foxall T, Valeri CR, Loscalzo J. Induction of platelet formation from megakaryocytoid cells by nitric oxide. Proc Natl Acad Sci U S A. 2001;98(25):14458-14463.

29. Giustarini D, Milzani A, Colombo R, Dalle-Donne I, Rossi R. Nitric oxide and S-nitrosothiols in human blood. Clin Chim Acta. 2003;330(1-2):85-98.

30. Lamas S, Marsden PA, Li GK, Tempst P, Michel T. Endothelial nitric oxide synthase: molecular cloning and characterization of a distinct constitutive enzyme isoform. Proc Natl Acad Sci U S A. 1992;89(14):6348-6352.

31. Palmer RM, Ashton DS, Moncada S. Vascular endothelial cells synthesize nitric oxide from L-arginine. Nature. 1988;333(6174):664-666.

32. Marletta MA. Nitric oxide synthase: aspects concerning structure and catalysis. Cell. 1994;78(6):927-930.

33. Murad F, Mittal CK, Arnold WP, Katsuki S, Kimura H. Guanylate cyclase: activation by azide, nitro compounds, nitric oxide, and hydroxyl radical and inhibition by hemoglobin and myoglobin. Adv Cyclic Nucleotide Res. 1978;9:145-158.

34. Eberhardt R. Loscalzo J. Nitric Oxide and the Cardiovascular System. Humana Press Inc. New York City; 2000.

35. Krumenacker JS, Hanafy KA, Murad F. Regulation of nitric oxide and soluble guanylyl cyclase. Brain Res Bull. 2004;62(6):505-515. 
36. Masters BS, McMillan K, Sheta EA, Nishimura JS, Roman LJ, Martasek P. Neuronal nitric oxide synthase, a modular enzyme formed by convergent evolution: structure studies of a cysteine thiolate-liganded heme protein that hydroxylates L-arginine to produce $\mathrm{NO}$ as a cellular signal. FASEB J. 1996;10(5):552-558.

37. Abu-Soud HM, Feldman PL, Clark P, Stuehr DJ. Electron transfer in the nitric-oxide synthases. Characterization of L-arginine analogs that block heme iron reduction. J Biol Chem. 1994;269(51):32318-32326.

38. Bredt DS, Snyder SH. Isolation of nitric oxide synthetase, a calmodulinrequiring enzyme. Proc Natl Acad Sci U S A. 1990;87(2):682-685.

39. Nathan C, Xie QW. Regulation of biosynthesis of nitric oxide. J Biol Chem. 1994;269(19):13725-13728.

40. Ding AH, Nathan CF, Stuehr DJ. Release of reactive nitrogen intermediates and reactive oxygen intermediates from mouse peritoneal macrophages. Comparison of activating cytokines and evidence for independent production. J Immunol. 1988;141(7):2407-2412.

41. Marriott HM, Ali F, Read RC, Mitchell TJ, Whyte MK, Dockrell DH. Nitric oxide levels regulate macrophage commitment to apoptosis or necrosis during pneumococcal infection. FASEB J. 2004;18(10): 1126-1128.

42. Stamler JS, Singel DJ, Loscalzo J. Biochemistry of nitric oxide and its redox-activated forms. Science. 1992;258(5090):1898-1902.

43. Feelisch M, te Poel M, Zamora R, Deussen A, Moncada S. Understanding the controversy over the identity of EDRF. Nature. 1994; 368(6466):62-65.

44. Stamler JS, Simon DI, Osborne JA, et al. S-nitrosylation of proteins with nitric oxide: synthesis and characterization of biologically active compounds. Proc Natl Acad Sci U S A. 1992;89(1):444-448.

45. Stamler JS, Slivka A. Biological chemistry of thiols in the vasculature and in vascular-related disease. Nutr Rev. 1996;54(1 Pt 1): $1-30$.

46. Aleryani S, Milo E, Rose Y, Kostka P. Superoxide-mediated decomposition of biological S-nitrosothiols. J Biol Chem. 1998;273(11) 6041-6045.

47. Yang Y, Loscalzo J. S-nitrosoprotein formation and localization in endothelial cells. Proc Natl Acad Sci U S A. 2005;102(1):117-122.

48. Hogg N. The biochemistry and physiology of S-nitrosothiols. Annu Rev Pharmacol Toxicol. 2002;42:585-600.

49. Jia L, Bonaventura C, Bonaventura J, Stamler JS. S-nitrosohaemoglobin: a dynamic activity of blood involved in vascular control. Nature. 1996;380(6571):221-226.

50. Pawloski JR, Hess DT, Stamler JS. Export by red blood cells of nitric oxide bioactivity. Nature. 2001;409(6820):622-626.

51. Datta B, Tufnell-Barrett T, Bleasdale RA, et al. Red blood cell nitric oxide as an endocrine vasoregulator: a potential role in congestive heart failure. Circulation. 2004;109(11):1339-1342.

52. James PE, Lang D, Tufnell-Barret T, Milsom AB, Frenneaux MP. Vasorelaxation by red blood cells and impairment in diabetes: reduced nitric oxide and oxygen delivery by glycated hemoglobin. Circ Res. 2004;94(7):976-983

53. McMahon TJ, Ahearn GS, Moya MP, et al. A nitric oxide processing defect of red blood cells created by hypoxia: deficiency of S-nitrosohemoglobin in pulmonary hypertension. Proc Natl Acad Sci U S A. 2005;102(41):14801-14806.

54. Allen BW, Stamler JS, Piantadosi CA. Hemoglobin, nitric oxide and molecular mechanisms of hypoxic vasodilation. Trends $\mathrm{Mol} \mathrm{Med}$. 2009;15(10):452-460.

55. Radi R, Beckman JS, Bush KM, Freeman BA. Peroxynitrite oxidation of sulfhydryls. The cytotoxic potential of superoxide and nitric oxide. J Biol Chem. 1991;266(7):4244-4250.

56. Miles AM, Bohle DS, Glassbrenner PA, Hansert B, Wink DA, Grisham MB. Modulation of superoxide-dependent oxidation and hydroxylation reactions by nitric oxide. J Biol Chem. 1996;271(1):40-47.

57. Virag L, Szabo E, Gergely P, Szabo C. Peroxynitrite-induced cytotoxicity: mechanism and opportunities for intervention. Toxicol Lett. 2003;140-141:113-124.

58. Steinberg D. Low density lipoprotein oxidation and its pathobiological significance. J Biol Chem. 1997;272(34):20963-20966.
59. Chen LY, Mehta P, Mehta JL. Oxidized LDL decreases L-arginine uptake and nitric oxide synthase protein expression in human platelets: relevance of the effect of oxidized LDL on platelet function. Circulation. 1996;93(9):1740-1746.

60. Abu-Soud HM, Rousseau DL, Stuehr DJ. Nitric oxide binding to the heme of neuronal nitric-oxide synthase links its activity to changes in oxygen tension. J Biol Chem. 1996;271(51):32515-32518.

61. Hurshman AR, Marletta MA. Nitric oxide complexes of inducible nitric oxide synthase: spectral characterization and effect on catalytic activity. Biochemistry. 1995;34(16):5627-5634.

62. Stuehr DJ. Structure-function aspects in the nitric oxide synthases. Annu Rev Pharmacol Toxicol. 1997;37:339-359.

63. Griscavage JM, Fukuto JM, Komori Y, Ignarro LJ. Nitric oxide inhibits neuronal nitric oxide synthase by interacting with the heme prosthetic group. Role of tetrahydrobiopterin in modulating the inhibitory action of nitric oxide. J Biol Chem. 1994;269(34):21644-21649.

64. Sagami I, Daff S, Shimizu T. Intra-subunit and inter-subunit electron transfer in neuronal nitric-oxide synthase: effect of calmodulin on heterodimer catalysis. J Biol Chem. 2001;276(32): 30036-30042.

65. Siddhanta U, Wu C, Abu-Soud HM, Zhang J, Ghosh DK, Stuehr DJ. Heme iron reduction and catalysis by a nitric oxide synthase heterodimer containing one reductase and two oxygenase domains. $J$ Biol Chem. 1996;271(13):7309-7312.

66. Albakri QA, Stuehr DJ. Intracellular assembly of inducible NO synthase is limited by nitric oxide-mediated changes in heme insertion and availability. J Biol Chem. 1996;271(10):5414-5421.

67. Simell O. Lysinuric protein intolerance and other cationic aminoacidurias. In: Scriver $\mathrm{CH}$, Beaudet $\mathrm{AL}$, Sly WS, Valle D, editors. The Metabolic and Molecular Bases of Inherited Disease. New York: McGraw-Hill; 1995:3603-3627.

68. Kamada Y, Nagaretani H, Tamura S, et al. Vascular endothelial dysfunction resulting from L-arginine deficiency in a patient with lysinuric protein intolerance. J Clin Invest. 2001;108(5):717-724.

69. Kayanoki Y, Kawata S, Yamasaki E, et al. Reduced nitric oxide production by L-arginine deficiency in lysinuric protein intolerance exacerbates intravascular coagulation. Metabolism. 1999;48(9):1136-1140.

70. Loscalzo J. An experiment of nature: genetic L-arginine deficiency and NO insufficiency. J Clin Invest. 2001;108(5):633-664.

71. Loscalzo J. What we know and don't know about L-arginine and NO. Circulation. 2000;101(18):2126-2129.

72. Cooke JP, Andon NA, Girerd XJ, Hirsch AT, Creager MA. Arginine restores cholinergic relaxation of hypercholesterolemic rabbit thoracic aorta. Circulation. 1991;83(3):1057-1062.

73. Lekakis JP, Papathanassiou S, Papaioannou TG, et al. Oral L-arginine improves endothelial dysfunction in patients with essential hypertension. Int J Cardiol. 2002;86(2-3):317-323.

74. Quyyumi AA, Dakak N, Mulcahy D, et al. Nitric oxide activity in the atherosclerotic human coronary circulation. $\mathrm{J} \mathrm{Am} \mathrm{Coll} \mathrm{Cardiol.}$ 1997;29(2):308-317.

75. Kaul DK, Zhang X, Dasgupta T, Fabry ME. Arginine therapy of transgenic-knockout sickle mice improves microvascular function by reducing non-nitric oxide vasodilators, hemolysis, and oxidative stress. Am J Physiol Heart Circ Physiol. 2008;295(1):H39-H47.

76. Javanmard SH, Nematbakhsh M, Mahmoodi F, Mohajeri MR. 1-Arginine supplementation enhances eNOS expression in experimental model of hypercholesterolemic rabbits aorta. Pathophysiology. 2009;16(1):9-13.

77. Rector TS, Bank AJ, Mullen KA, et al. Randomized, doubleblind, placebo-controlled study of supplemental oral L-arginine in patients with heart failure. Circulation. 1996;93(12): 2135-2141.

78. Wilson AM, Harada R, Nair N, Balasubramanian N, Cooke JP. L-arginine supplementation in peripheral arterial disease: no benefit and possible harm. Circulation. 2007;116(2):188-195.

79. Blum A, Hathaway L, Mincemoyer R, et al. Oral L-arginine in patients with coronary artery disease on medical management. Circulation. 2000;101(18):2160-2164. 
80. Walker HA, McGing E, Fisher I, et al. Endothelium-dependent vasodilation is independent of the plasma L-arginine/ADMA ratio in men with stable angina: lack of effect of oral L-arginine on endothelial function, oxidative stress and exercise performance. J Am Coll Cardiol. 2001;38(2):499-505.

81. Bednarz B, Jaxa-Chamiec T, Maciejewski P, et al. Efficacy and safety of oral 1-arginine in acute myocardial infarction. Results of the multicenter, randomized, double-blind, placebo-controlled ARAMI pilot trial. Kardiol Pol. 2005;62(5):421-427.

82. Zieman SJ, Gerstenblith G, Lakatta EG, et al. Upregulation of the nitric oxide-cGMP pathway in aged myocardium: physiological response to 1-arginine. Circ Res. 2001;88(1):97-102.

83. Vallance P, Leone A, Calver A, Collier J, Moncada S. Endogenous dimethylarginine as an inhibitor of nitric oxide synthesis. J Cardiovasc Pharmacol. 1992;20(Suppl 12):S60-S62.

84. Boger RH. The emerging role of asymmetric dimethylarginine as a novel cardiovascular risk factor. Cardiovasc Res. 2003;59(4):824-833.

85. Boger RH, Bode-Boger SM, Szuba A, et al. Asymmetric dimethylarginine (ADMA): a novel risk factor for endothelial dysfunction: its role in hypercholesterolemia. Circulation. 1998;98(18):1842-1847.

86. Sydow K, Schwedhelm E, Arakawa N, et al. ADMA and oxidative stress are responsible for endothelial dysfunction in hyperhomocyst(e) inemia: effects of L-arginine and B vitamins. Cardiovasc Res. 2003;57(1):244-252.

87. Surdacki A, Nowicki M, Sandmann J, et al. Reduced urinary excretion of nitric oxide metabolites and increased plasma levels of asymmetric dimethylarginine in men with essential hypertension. J Cardiovasc Pharmacol. 1999;33(4):652-658.

88. Kielstein JT, Bode-Boger SM, Hesse G, et al. Asymmetrical dimethylarginine in idiopathic pulmonary arterial hypertension. Arterioscler Thromb Vasc Biol. 2005;25(7):1414-1418.

89. Nishiyama Y, Ueda M, Katsura K, et al. Asymmetric dimethylarginine (ADMA) as a possible risk marker for ischemic stroke. J Neurol Sci. 290(1-2):12-15.

90. Yamagishi S, Ueda S, Nakamura K, Matsui T, Okuda S. Role of asymmetric dimethylarginine (ADMA) in diabetic vascular complications. Curr Pharm Des. 2008;14(25):2613-2618.

91. Ding H, Wu B, Wang H, et al. A novel loss-of-function DDAH1 promoter polymorphism is associated with increased susceptibility to thrombosis stroke and coronary heart disease. Circ Res. 2010;106(6):1145-1152.

92. Rodionov RN, Dayoub H, Lynch CM, et al. Overexpression of dimethylarginine dimethylaminohydrolase protects against cerebral vascular effects of hyperhomocysteinemia. Circ Res. 2010;106(3):551-558.

93. Toth J, Racz A, Kaminski PM, Wolin MS, Bagi Z, Koller A. Asymmetrical dimethylarginine inhibits shear stress-induced nitric oxide release and dilation and elicits superoxide-mediated increase in arteriolar tone. Hypertension. 2007;49(3):563-568.

94. Kawano H, Motoyama T, Hirai N, Kugiyama K, Yasue H, Ogawa H. Endothelial dysfunction in hypercholesterolemia is improved by L-arginine administration: possible role of oxidative stress. Atherosclerosis. 2002;161(2):375-380.

95. Creager MA, Gallagher SJ, Girerd XJ, Coleman SM, Dzau VJ, Cooke JP. L-arginine improves endothelium-dependent vasodilation in hypercholesterolemic humans. J Clin Invest. 1992;90(4):1248-1253.

96. Thorne S, Mullen MJ, Clarkson P, Donald AE, Deanfield JE. Early endothelial dysfunction in adults at risk from atherosclerosis: different responses to L-arginine. J Am Coll Cardiol. 1998;32(1): 110-116.

97. Lerman A, Burnett JC Jr, Higano ST, McKinley LJ, Holmes DR Jr. Long-term L-arginine supplementation improves small-vessel coronary endothelial function in humans. Circulation. 1998;97(21): 2123-2128.

98. Nelin LD, Hoffman GM. L-arginine infusion lowers blood pressure in children. J Pediatr. 2001;139(5):747-749.

99. Fleming I, Busse R. Molecular mechanisms involved in the regulation of the endothelial nitric oxide synthase. Am J Physiol Regul Integr Comp Physiol. 2003;284(1):R1-R12.
100. Govers R, Rabelink TJ. Cellular regulation of endothelial nitric oxide synthase. Am J Physiol Renal Physiol. 2001;280(2):F193-F206.

101. Garcia-Cardena G, Oh P, Liu J, Schnitzer JE, Sessa WC. Targeting of nitric oxide synthase to endothelial cell caveolae via palmitoylation: implications for nitric oxide signaling. Proc Natl Acad Sci U S A. 1996;93(13):6448-6453.

102. Liu J, Garcia-Cardena G, Sessa WC. Palmitoylation of endothelial nitric oxide synthase is necessary for optimal stimulated release of nitric oxide: implications for caveolae localization. Biochemistry. 1996;35(41):13277-13281.

103. Nadaud S, Philippe M, Arnal JF, Michel JB, Soubrier F. Sustained increase in aortic endothelial nitric oxide synthase expression in vivo in a model of chronic high blood flow. Circ Res. 1996;79(4):857-863.

104. Topper JN, Cai J, Falb D, Gimbrone MA Jr. Identification of vascular endothelial genes differentially responsive to fluid mechanical stimuli: cyclooxygenase-2, manganese superoxide dismutase, and endothelial cell nitric oxide synthase are selectively up-regulated by steady laminar shear stress. Proc Natl Acad Sci U S A. 1996;93(19): 10417-10422.

105. Uematsu M, Ohara Y, Navas JP, et al. Regulation of endothelial cell nitric oxide synthase mRNA expression by shear stress. Am J Physiol. 1995;269(6 Pt 1):C1371-C1378.

106. Weber M, Hagedorn CH, Harrison DG, Searles CD. Laminar shear stress and 3' polyadenylation of eNOS mRNA. Circ Res. 2005;96(11):1161-1168.

107. Tuttle JL, Nachreiner RD, Bhuller AS, et al. Shear level influences resistance artery remodeling: wall dimensions, cell density, and eNOS expression. Am J Physiol Heart Circ Physiol. 2001;281(3): H1380-H1389.

108. Davis ME, Cai H, Drummond GR, Harrison DG. Shear stress regulates endothelial nitric oxide synthase expression through c-Src by divergent signaling pathways. Circ Res. 2001;89(11):1073-1080.

109. Weber M, Baker MB, Moore JP, Searles CD. MiR-21 is induced in endothelial cells by shear stress and modulates apoptosis and eNOS activity. Biochem Biophys Res Commun. 2010;393(4): 643-648.

110. Wang Y, Lee CG. MicroRNA and cancer - focus on apoptosis. J Cell Mol Med. 2009;13(1):12-23.

111. Arnal JF, Yamin J, Dockery S, Harrison DG. Regulation of endothelial nitric oxide synthase mRNA, protein, and activity during cell growth. Am J Physiol. 1994;267(5 Pt 1):C1381-C1388.

112. Poppa V, Miyashiro JK, Corson MA, Berk BC. Endothelial NO synthase is increased in regenerating endothelium after denuding injury of the rat aorta. Arterioscler Thromb Vasc Biol. 1998;18(8):1312-1321.

113. Searles CD, Miwa Y, Harrison DG, Ramasamy S. Posttranscriptional regulation of endothelial nitric oxide synthase during cell growth. Circ Res. 1999;85(7):588-595.

114. Thomas SR, Chen K, Keaney JF Jr. Hydrogen peroxide activates endothelial nitric-oxide synthase through coordinated phosphorylation and dephosphorylation via a phosphoinositide 3-kinase-dependent signaling pathway. J Biol Chem. 2002;277(8):6017-6024.

115. Drummond GR, Cai H, Davis ME, Ramasamy S, Harrison DG. Transcriptional and posttranscriptional regulation of endothelial nitric oxide synthase expression by hydrogen peroxide. Circ Res. 2000;86(3):347-354.

116. Cai H, Davis ME, Drummond GR, Harrison DG. Induction of endothelial NO synthase by hydrogen peroxide via a $\mathrm{Ca}(2+) /$ calmodulindependent protein kinase II/janus kinase 2-dependent pathway. Arterioscler Thromb Vasc Biol. 2001;21(10):1571-1576.

117. Kumar S, Sud N, Fonseca FV, Hou Y, Black SM. Shear stress stimulates nitric oxide signaling in pulmonary arterial endothelial cells via a reduction in catalase activity: role of protein kinase C delta. Am J Physiol Lung Cell Mol Physiol. 2010;298(1): L105-L116.

118. Tian J, Hou Y, Lu Q, et al. A novel role for caveolin-1 in regulating endothelial nitric oxide synthase activation in response to $\mathrm{H}(2) \mathrm{O}(2)$ and shear stress. Free Radic Biol Med. Epub 2010 Mar 29. 
119. Toporsian M, Govindaraju K, Nagi M, Eidelman D, Thibault G, Ward ME. Downregulation of endothelial nitric oxide synthase in rat aorta after prolonged hypoxia in vivo. Circ Res. 2000;86(6): 671-675.

120. Le Cras TD, Tyler RC, Horan MP, et al. Effects of chronic hypoxia and altered hemodynamics on endothelial nitric oxide synthase expression in the adult rat lung. J Clin Invest. 1998;101(4):795-801.

121. Hoehn T, Stiller B, McPhaden AR, Wadsworth RM. Nitric oxide synthases in infants and children with pulmonary hypertension and congenital heart disease. Respir Res. 2009;10:110.

122. Giaid A, Saleh D. Reduced expression of endothelial nitric oxide synthase in the lungs of patients with pulmonary hypertension. $N$ Engl J Med. 1995;333(4):214-221.

123. Liao JK, Shin WS, Lee WY, Clark SL. Oxidized low-density lipoprotein decreases the expression of endothelial nitric oxide synthase. J Biol Chem. 1995;270(1):319-324.

124. de Caterina R, Libby P, Peng HB, et al. Nitric oxide decreases cytokineinduced endothelial activation. Nitric oxide selectively reduces endothelial expression of adhesion molecules and proinflammatory cytokines. J Clin Invest. 1995;96(1):60-68.

125. Kubes P, Suzuki M, Granger DN. Nitric oxide: an endogenous modulator of leukocyte adhesion. Proc Natl Acad Sci U S A. 1991;88(11):4651-4655.

126. Takaya T, Hirata K, Yamashita T, et al. A specific role for eNOSderived reactive oxygen species in atherosclerosis progression. Arterioscler Thromb Vasc Biol. 2007;27(7):1632-1637.

127. Wilcox JN, Subramanian RR, Sundell CL, et al. Expression of multiple isoforms of nitric oxide synthase in normal and atherosclerotic vessels. Arterioscler Thromb Vasc Biol. 1997;17(11):2479-2488.

128. Maas R, Schwedhelm E, Kahl L, et al. Simultaneous assessment of endothelial function, nitric oxide synthase activity, nitric oxidemediated signaling, and oxidative stress in individuals with and without hypercholesterolemia. Clin Chem. 2008;54(2):292-300.

129. Hayashi T, Juliet PA, Matsui-Hirai H, et al. 1-Citrulline and 1-arginine supplementation retards the progression of high-cholesterol-dietinduced atherosclerosis in rabbits. Proc Natl Acad Sci U S A. 2005; 102(38):13681-13686.

130. Nematbakhsh M, Haghjooyjavanmard S, Mahmoodi F, Monajemi AR. The prevention of endothelial dysfunction through endothelial cell apoptosis inhibition in a hypercholesterolemic rabbit model: the effect of L-arginine supplementation. Lipids Health Dis. 2008;7:27.

131. Freedman JE, Sauter R, Battinelli EM, et al. Deficient platelet-derived nitric oxide and enhanced hemostasis in mice lacking the NOSIII gene. Circ Res. 1999;84(12):1416-1421.

132. Freedman JE, Loscalzo J, Benoit SE, Valeri CR, Barnard MR, Michelson AD. Decreased platelet inhibition by nitric oxide in two brothers with a history of arterial thrombosis. J Clin Invest. 1996;97(4):979-987.

133. Bakdash N, Williams MS. Spatially distinct production of reactive oxygen species regulates platelet activation. Free Radic Biol Med. 2008;45(2):158-166.

134. Pignatelli P, Pulcinelli FM, Lenti L, Gazzaniga PP, Violi F. Hydrogen peroxide is involved in collagen-induced platelet activation. Blood. 1998;91(2):484-490.

135. Freedman JE, Loscalzo J, Barnard MR, Alpert C, Keaney JF Jr, Michelson AD. Nitric oxide released from activated platelets inhibits platelet recruitment. J Clin Invest. 1997;100(2):350-356.

136. Voetsch B, Jin RC, Bierl C, et al. Promoter polymorphisms in the plasma glutathione peroxidase (GPx-3) gene: a novel risk factor for arterial ischemic stroke among young adults and children. Stroke. 2007;38(1):41-49.

137. Voetsch B, Jin RC, Bierl C, et al. Role of promoter polymorphisms in the plasma glutathione peroxidase (GPx-3) gene as a risk factor for cerebral venous thrombosis. Stroke. 2008;39(2):303-307.

138. Panza JA, Casino PR, Kilcoyne CM, Quyyumi AA. Role of endothelium-derived nitric oxide in the abnormal endotheliumdependent vascular relaxation of patients with essential hypertension. Circulation. 1993;87(5):1468-1474.
139. Panza JA, Garcia CE, Kilcoyne CM, Quyyumi AA, Cannon RO 3rd. Impaired endothelium-dependent vasodilation in patients with essential hypertension. Evidence that nitric oxide abnormality is not localized to a single signal transduction pathway. Circulation. 1995;91(6):1732-1738.

140. Perticone F, Ceravolo R, Pujia A, et al. Prognostic significance of endothelial dysfunction in hypertensive patients. Circulation. 2001;104(2):191-196.

141. Morcos M, Borcea V, Isermann B, et al. Effect of alpha-lipoic acid on the progression of endothelial cell damage and albuminuria in patients with diabetes mellitus: an exploratory study. Diabetes Res Clin Pract. 2001;52(3):175-183.

142. Schalkwijk CG, Stehouwer CD. Vascular complications in diabetes mellitus: the role of endothelial dysfunction. Clin Sci (Lond) 2005;109(2):143-159.

143. Guzik TJ, Mussa S, Gastaldi D, et al. Mechanisms of increased vascular superoxide production in human diabetes mellitus: role of $\mathrm{NAD}(\mathrm{P}) \mathrm{H}$ oxidase and endothelial nitric oxide synthase. Circulation. 2002;105(14):1656-1662.

144. Hink U, Li H, Mollnau H, et al. Mechanisms underlying endothelial dysfunction in diabetes mellitus. Circ Res. 2001;88(2):E14-E22.

145. Vasquez-Vivar J, Kalyanaraman B, Martasek P, et al. Superoxide generation by endothelial nitric oxide synthase: the influence of cofactors. Proc Natl Acad Sci U S A. 1998;95(16):9220-9225.

146. Vasquez-Vivar J, Martasek P, Whitsett J, Joseph J, Kalyanaraman B. The ratio between tetrahydrobiopterin and oxidized tetrahydrobiopterin analogues controls superoxide release from endothelial nitric oxide synthase: an EPR spin trapping study. Biochem J. 2002;362 (Pt 3):733-739.

147. Cooke JP, Dzau J, Creager A. Endothelial dysfunction in hypercholesterolemia is corrected by L-arginine. Basic Res Cardiol. 1991;86 (Suppl 2):173-181.

148. Boger RH, Bode-Boger SM, Brandes RP, et al. Dietary L-arginine reduces the progression of atherosclerosis in cholesterol-fed rabbits: comparison with lovastatin. Circulation. 1997;96(4):1282-1290.

149. Closs EI, Scheld JS, Sharafi M, Forstermann U. Substrate supply for nitric-oxide synthase in macrophages and endothelial cells: role of cationic amino acid transporters. Mol Pharmacol. 2000;57(1):68-74.

150. Pollock JS, Forstermann U, Mitchell JA, et al. Purification and characterization of particulate endothelium-derived relaxing factor synthase from cultured and native bovine aortic endothelial cells. Proc Natl Acad Sci U S A. 1991;88(23):10480-10484.

151. Boucher JL, Moali C, Tenu JP. Nitric oxide biosynthesis, nitric oxide synthase inhibitors and arginase competition for L-arginine utilization. Cell Mol Life Sci. 1999;55(8-9):1015-1028.

152. Kajiya M, Hirota M, Inai $Y$, et al. Impaired NO-mediated vasodilation with increased superoxide but robust EDHF function in right ventricular arterial microvessels of pulmonary hypertensive rats. $\mathrm{Am}$ J Physiol Heart Circ Physiol. 2007;292(6):H2737-H2744.

153. Shimokawa H, Matoba T. Hydrogen peroxide as an endotheliumderived hyperpolarizing factor. Pharmacol Res. 2004;49(6): 543-549.

154. Fortuno A, Olivan S, Beloqui O, et al. Association of increased phagocytic NADPH oxidase-dependent superoxide production with diminished nitric oxide generation in essential hypertension. J Hypertens. 2004;22(11):2169-2175.

155. Zalba G, San Jose G, Moreno MU, Fortuno A, Diez J. NADPH oxidasemediated oxidative stress: genetic studies of the p22(phox) gene in hypertension. Antioxid Redox Signal. 2005;7(9-10):1327-1336.

156. Peixoto EB, Pessoa BS, Biswas SK, Lopes de Faria JB. Antioxidant SOD mimetic prevents NADPH oxidase-induced oxidative stress and renal damage in the early stage of experimental diabetes and hypertension. Am J Nephrol. 2009;29(4):309-318.

157. Sartoretto JL, Oliveira MA, Nigro D, Carvalho MH, Tostes RC, Fortes ZB. Constrictor responses to noradrenaline, hemodynamic profile, and superoxide levels measured by hydroethidine oxidation in diabetic rats. Biol Pharm Bull. 2007;30(10):1938-1942. 
158. Biswas SK, Peixoto EB, Souza DS, de Faria JB. Hypertension increases pro-oxidant generation and decreases antioxidant defense in the kidney in early diabetes. Am J Nephrol. 2008;28(1):133-142.

159. Dixon LJ, Hughes SM, Rooney K, et al. Increased superoxide production in hypertensive patients with diabetes mellitus: role of nitric oxide synthase. Am J Hypertens. 2005;18(6):839-843.

160. Hattori Y, Kawasaki H, Abe K, Kanno M. Superoxide dismutase recovers altered endothelium-dependent relaxation in diabetic rat aorta. Am J Physiol. 1991;261(4 Pt 2):H1086-H1094.

161. Inoguchi T, Li P, Umeda F, et al. High glucose level and free fatty acid stimulate reactive oxygen species production through protein kinase C-dependent activation of $\mathrm{NAD}(\mathrm{P}) \mathrm{H}$ oxidase in cultured vascular cells. Diabetes. 2000;49(11):1939-1945.

162. Serpillon S, Floyd BC, Gupte RS, et al. Superoxide production by $\mathrm{NAD}(\mathrm{P}) \mathrm{H}$ oxidase and mitochondria is increased in genetically obese and hyperglycemic rat heart and aorta before the development of cardiac dysfunction. The role of glucose-6-phosphate dehydrogenase-derived NADPH. Am J Physiol Heart Circ Physiol. 2009;297(1):H153-H162.

163. Xia L, Wang H, Munk S, et al. High glucose activates PKC-zeta and NADPH oxidase through autocrine TGF-beta1 signaling in mesangial cells. Am J Physiol Renal Physiol. 2008;295(6):F1705-F1714.

164. Du Y, Miller CM, Kern TS. Hyperglycemia increases mitochondrial superoxide in retina and retinal cells. Free Radic Biol Med. 2003;35(11):1491-1499.

165. Yeop Han C, Kargi AY, Omer M, et al. Differential effect of saturated and unsaturated free fatty acids on the generation of monocyte adhesion and chemotactic factors by adipocytes: dissociation of adipocyte hypertrophy from inflammation. Diabetes. 2010;59(2):386-396.

166. Gupte RS, Floyd BC, Kozicky M, et al. Synergistic activation of glucose-6-phosphate dehydrogenase and $\mathrm{NAD}(\mathrm{P}) \mathrm{H}$ oxidase by Src kinase elevates superoxide in type 2 diabetic, Zucker fa/fa, rat liver. Free Radic Biol Med. 2009;47(3):219-228.

167. Lin L, Park S, Lakatta EG. RAGE signaling in inflammation and arterial aging. Front Biosci. 2009;14:1403-1413.

168. Goldstein JL, Brown MS. Regulation of the mevalonate pathway. Nature. 1990;343(6257):425-430.

169. Lahera V, Goicoechea M, de Vinuesa SG, et al. Endothelial dysfunction, oxidative stress and inflammation in atherosclerosis: beneficial effects of statins. Curr Med Chem. 2007;14(2):243-248.

170. Endres M, Laufs U. Effects of statins on endothelium and signaling mechanisms. Stroke. 2004;35(11 Suppl 1):2708-2711.

171. Nohria A, Prsic A, Liu PY, et al. Statins inhibit Rho kinase activity in patients with atherosclerosis. Atherosclerosis. 2009;205(2): 517-521.

172. Laufs U, La Fata V, Plutzky J, Liao JK. Upregulation of endothelial nitric oxide synthase by HMG CoA reductase inhibitors. Circulation. 1998;97(12):1129-1135.

173. Wang J, Xu Z, Kitajima I, Wang Z. Effects of different statins on endothelial nitric oxide synthase and AKT phosphorylation in endothelial cells. Int J Cardiol. 2008;127(1):33-39.
174. Harris MB, Blackstone MA, Sood SG, et al. Acute activation and phosphorylation of endothelial nitric oxide synthase by $\mathrm{HMG}-\mathrm{CoA}$ reductase inhibitors. Am J Physiol Heart Circ Physiol. 2004;287(2): H560-H566.

175. Shinozaki K, Nishio Y, Ayajiki K, et al. Pitavastatin restores vascular dysfunction in insulin-resistant state by inhibiting $\mathrm{NAD}(\mathrm{P}) \mathrm{H}$ oxidase activity and uncoupled endothelial nitric oxide synthasedependent superoxide production. J Cardiovasc Pharmacol. 2007;49(3):122-130.

176. Takayama T, Wada A, Tsutamoto T, et al. Contribution of vascular $\mathrm{NAD}(\mathrm{P}) \mathrm{H}$ oxidase to endothelial dysfunction in heart failure and the therapeutic effects of HMG-CoA reductase inhibitor. Circ J. 2004;68(11):1067-1075.

177. Rothberg KG, Heuser JE, Donzell WC, Ying YS, Glenney JR, Anderson RG. Caveolin, a protein component of caveolae membrane coats. Cell. 1992;68(4):673-682.

178. Gratton JP, Bernatchez P, Sessa WC. Caveolae and caveolins in the cardiovascular system. Circ Res. 2004;94(11):1408-1417.

179. Feron O, Belhassen L, Kobzik L, Smith TW, Kelly RA, Michel T. Endothelial nitric oxide synthase targeting to caveolae. Specific interactions with caveolin isoforms in cardiac myocytes and endothelial cells. J Biol Chem. 1996;271(37):22810-22814.

180. Suh J-W, Choi D-J, Chang H-J, et al. HMG-COA reductase inhibitor improves endothelial dysfunction in spontaneous hypetensive rats via down-regulation of caveolin-1 and activation of endothelial nitric oxide. J Korean Med Sci. 2010;25:16-23.

181. Ji Y, Bennett BM. Biotransformation of glyceryl trinitrate by rat hepatic microsomal glutathione S-transferase 1. J Pharmacol Exp Ther. 2006;318(3):1050-1056.

182. Govoni M, Casagrande S, Maucci R, Chiroli V, Tocchetti P. In vitro metabolism of (nitrooxy)butyl ester nitric oxide-releasing compounds: comparison with glyceryl trinitrate. J Pharmacol Exp Ther. 2006;317(2):752-761

183. Millar TM, Stevens CR, Benjamin N, Eisenthal R, Harrison R, Blake DR. Xanthine oxidoreductase catalyses the reduction of nitrates and nitrite to nitric oxide under hypoxic conditions. FEBS Lett. 1998;427(2):225-228.

184. Chen Z, Foster MW, Zhang J, et al. An essential role for mitochondrial aldehyde dehydrogenase in nitroglycerin bioactivation. Proc Natl Acad Sci US A. 2005;102(34):12159-12164.

185. Laslett LJ, Baker L. Sublingual nitroglycerin administered by spray versus tablet: comparative timing of hemodynamic effects. Cardiology. 1990;77(4):303-310.

186. Bauer JA, Fung HL. Arterial versus venous metabolism of nitroglycerin to nitric oxide: a possible explanation of organic nitrate venoselectivity. J Cardiovasc Pharmacol. 1996;28(3):371-374.

187. Bonini MG, Stadler K, Silva SO, et al. Constitutive nitric oxide synthase activation is a significant route for nitroglycerin-mediated vasodilation. Proc Natl Acad Sci U S A. 2008;105(25):8569-8574.
Journal of Blood Medicine

\section{Publish your work in this journal}

The Journal of Blood Medicine is an international, peer-reviewed, open access, online journal publishing laboratory, experimental and clinical aspects of all topics pertaining to blood based medicine including but not limited to: Transfusion Medicine; Blood collection, Donor issues, Transmittable diseases, and Blood banking logistics; Immunohematology; Artificial and alternative

\section{Dovepress}

blood based therapeutics; Hematology; Biotechnology/nanotechnology of blood related medicine; Legal aspects of blood medicine; Historical perspectives. The manuscript management system is completely online and includes a very quick and fair peer-review system. Visit http://www.dovepress.com/ testimonials.php to read real quotes from published authors. 